\title{
Expertise and National Planning
}

\begin{abstract}
This chapter looks into the development of Indonesia's postcolonial higher education system and the international technical assistance protocol in developing Indonesia's new managerial class. It looks into the rapid expansion of higher education and the effort of the Indonesian society to decolonize its education system away from the Dutch model. Because of the swiftness of this process, Indonesianization looked a lot like Americanization. International aid through technical assistance was the primary means through which Western ideas on development planning and expert production through international higher education became cemented. Aid money helped create personal and institutional relationships between Indonesian and American government institutions and universities. In particular, the relationship between experts like the economist Sumitro Djojohadikusumo, Indonesia's state planning institution, the faculty of economics of the University of Indonesia and UN and USAID technical experts and Western social scientists from American within MIT's Indonesia Project and others. These forms of transnational relationships legitimized the position of Indonesian planning experts within planning institutions that had strong institutional relationship with the West. This pattern would continue throughout much of the twentieth century.
\end{abstract}

\section{Keywords}

Indonesianization of higher education - Americanization - international technical aid - modernization theory - Indonesia project

This chapter discusses two developments concerning the post-colonial creation of expertise during the 1950s. The first was the development of higher education in both quantitative and qualitative terms: this included the expansion of domestic tertiary education and the Americanization of the curriculum and study methods, as well as the introduction of the Guided Study method. The second was the development of the various institutes for national planning and economic development, which was the result of a new institutional relationship forged by Sumitro Djojohadikusumo with the UNTAA (United Nations 
Technical Assistance Administration) and American aid in the form of an intellectual association with the Charles River (Harvard-MIT) community of scholars.

The developments above represented the defining characteristics of the changing elite culture of the 1950s. First, the decade was a period in which efforts to erase the colonial legacy were made in various aspects of national life. One of the most famous of these efforts was the nationalization of Dutch-owned enterprises. Yet, Indonesianization occurred in more areas than just the economy. It was prevalent in the education, legal, and administrative systems, among others. Indonesia sought foreign expertise and consultants through the only channel available in that period: the international aid structure dominated by the United States of America. In many respects, Indonesianization was Americanization.

Second, the establishment of institutions for national planning and economic development resulted in a new protocol for elite creation that was cemented during the decade. The shift towards being educated as a marker of elite status was significant, with education surpassing nobility as a class marker. A new elite emerged from the social and cultural shift brought about by the introduction of the fetish of efficiency and the lexicographic assault of English terminology to denote modernity: efficiency, planning, manager and management, and so forth. Terms such as 'expert' and 'manager' became markers of status.

When the Dutch transferred sovereignty, the problem of the lack of expertise was already apparent. The number of Dutch experts in Indonesia fell throughout the 1950s. In 1950, there were more than sixteen thousand Dutch employees in leading positions; by 1951, the number had already dropped to seven thousand; and by 1956, it had atrophied to around six hundred. ${ }^{1}$ Difficulties at the office owing to the unclear division of tasks and responsibilities, which were exacerbated by the rising cost of living, lack of security, poor housing, and the disappearance of good schools for their children, determined the decision of many Dutch to repatriate. ${ }^{2}$ This occurred despite efforts by the Dutch and

1 Meier, Den Haag-Djakarta, 176.

2 Nota omtrent de ontwikkeling van zaken in Indonesië in zoverre de verhoudingen binnen de Nederlands-Indonesische Unie en de belangen van Nederland daarbij betrokken zijn, NA, Ministerie van Buitenlandse Zaken, Hoge Commissariaat Bandung, 1950-1957, inv. nos. 556566 . 
Indonesian governments to retain their presence. For instance, the Dutch employees of the Republic were reassured by a regulation issued on 1 January $195^{\circ}$ by the Dutch government regarding the continued payment of pensions and other support for those who worked for the Indonesian government. ${ }^{3}$

The government's efforts to improve expertise in the civil service entailed two approaches: retaining or conscripting foreign employees and, at the same time, expanding education opportunities for Indonesian employees, either in Indonesia or abroad. Dutch employees were preferred by Indonesia's administrative elites. They knew Indonesia far better than experts from other countries. The higher-echelon Indonesian civil servants spoke Dutch and thus communication between Indonesian and Dutch experts was less of a problem. The abilities of the Dutch employees were not in doubt and, to some extent, were considered to be superior to those of other Western nations. ${ }^{4}$ There were quite a number of new Dutch employees who were generally progressive. ${ }^{5}$

Indonesia also began sending students abroad to foreign universities and expanding its own higher-education offering. In 1960, the Depernas tried to get an overall picture of the number of experts in the country from government departments and institutions. The outcome was not accurate, because some departments failed to provide or provided incomplete information, but the aggregate number offers an indication of the expansion of expert manpower by the end of the decade. In all, there were 4,453 Masters/Doctorandus degrees held, comprised of 1,659 medical doctors, 803 legal specialists, 650 engineers, 219 social/political scientists, and 200 economists, among others. In addition, there were 2,519 employees with bachelor's degrees (469 majoring in social/ political sciences, 221 in economics, 282 in law, and 198 in engineering). ${ }^{6}$

Related to this was a serious lack of executive managers. A look at the statistics for 1941 reveals a ratio of three executives to five non-executives. The top-level executives were university graduates, while the upper mid-level executives were graduates of college-level academies ${ }^{7}$. In comparison, the 1961 data show that the executive and top-executive level had shrunk to just 3.5 per

3 Antara, 30 December 1952.

4 With the exception of the Netherlands Military Mission, which was disparaged by Simatupang in a newspaper article. ANRI, Delegasi Indonesia, inv. no. 1267.

5 Sjafruddin Prawiranegara, Indonesia Dipersimpangan Djalan (Djakarta: Abadi, 1951), 37-8.

6 Rantjangan Dasar Undang-undang Pembangunan Nasional Semesta, Buku Ke III, 1388-9.

7 Such as the HBs (Hogere Burger School), the Dutch High School; gymnasia are Dutch preparatory schools for higher or university education; the Mosvia (Middelbare Opleiding School voor Inlandsche Ambtenaren, High School for Indigenous Civil Servants), the college for native civil service candidates (Pamong Pradja); and the Bestuursacademie, an administrative school. 
TABLE 1 Data and levels of employment of civil servants, Dutch East Indies, October 1940

\begin{tabular}{lllll}
\hline & $\begin{array}{l}\text { Workers } \\
\text { (low-level } \\
\text { employees) }\end{array}$ & $\begin{array}{l}\text { Supervisors } \\
\text { (lower } \\
\text { mid-level } \\
\text { employees) }\end{array}$ & $\begin{array}{l}\text { Executives } \\
\text { (upper } \\
\text { mid-level } \\
\text { employees) }\end{array}$ & $\begin{array}{l}\text { Top ex./ } \\
\text { policymakers } \\
\text { (high-level } \\
\text { employees) }\end{array}$ \\
\hline Dutch & 355 & 5,045 & 7,909 & 2,808 \\
Indonesian & 49,662 & 8,830 & 5,023 & 221 \\
Chinese & 157 & 337 & 240 & - \\
Total & 50,178 & 14,212 & 13,172 & 3,029 \\
Percentage & $61.78 \%$ & $17 \cdot 49 \%$ & $16.21 \%$ & $3 \cdot 75 \%$ \\
Ratio & 20 & 6 & 5 & 1 \\
\hline
\end{tabular}

SOURCE: PRAJUDI ATMOSUDIRDJO, 'MASALAH PENDIDIKAN ILMU ADMINISTRASI PADA PERGURUAN-PERGURUAN TINGGI', IN LAPURAN MUSJAWARAH ILMU ADMINISTRASI NEGARA DAN NIAGA, 33

cent of the total civil service (E and F group). In order to return to 1941 levels, the creation of eight to ten thousand public administration experts would be required, something which the four universities teaching public administration were not equipped to handle with their annual graduations of just two hundred people. ${ }^{8}$ In Table 2 below, the A and B columns represent workers, $\mathrm{C}$ and D represent supervisors, E represents executives, and F represents top executives. The third row shows the ratio; thus there were five executives for every ninety-five non-executive civil servants.

The Centre for Foreign Employees (Pusat Tenaga Bangsa Asing, PUTABA) was established in 1951 at the Indonesian High Commission in The Hague. It was created after a team headed by Prof Gunarso from the гтв, Prof Sukarja, and Masoro, head of the General Directorate of the Ministry of Personnel Affairs (Kementerian Negara Urusan Pegawai), led a team on a visit to the city in June of that year. They were sent to Europe to look into the possibility of importing

8 Prajudi Atmosudirdjo, 'Masalah Pendidikan Ilmu Administrasi pada Perguruan-perguruan Tinggi', in Lapuran Musjawarah Ilmu Administrasi Negara dan Niaga (Jakarta: Lembaga Administrasi Negara, 1962), 32-4. 
TABLE 2 Levels of employment of civil servants, Indonesia, January 1961

\begin{tabular}{llllll}
\hline A & B & C & D & E & F \\
\hline 228,889 & 408,302 & 170,901 & 100,568 & 28,687 & 7,679 \\
$21.9 \%$ & $39.1 \%$ & $16.28 \%$ & $9.63 \%$ & $2.74 \%$ & $0.72 \%$ \\
84 & & 36 & & 4 & 1 \\
\hline
\end{tabular}

Note: The A and B columns represent workers, C and D represent supervisors, E represents executives, and F represents top executives. The third bracket shows the ratio, thus there were five executives for every ninety-five non-executive civil servants.

SOURCE: ATMOSUDIRDJO, 'MASALAH PENDIDIKAN ILMU ADMINISTRASI', IN LAPURAN MUSYAWARAH ILMU ADMINISTRASI NEGARA DAN NIAGA, 33

experts. The team's itinerary included the Netherlands, Germany, Austria, and Switzerland. The team did not go to the UK, instead focusing on 'Germanspeaking' countries. ${ }^{9}$

In 1950, the commission set up to study the matter of hiring foreign employees surveyed various ministries to determine the number of vacancies available. Between one thousand seven hundred and two thousand foreign experts were needed. Foreign employees on temporary contracts were offered all kinds of perks and benefits, and paid higher wages than Indonesians in the same positions. Yet, by September 1951, only one hundred people had been recruited for a three-year contract. The government provided residences in the Kebajoran Baru district of Jakarta. In the advertisements published in Austria, a very large salary of Rp 1,810 a month was promised, in addition to a fl. 13,0oo bonus to be paid out in Austria after the three-year contract period. On 21 August 1952, seventeen medical doctors from various European countries arrived in Jakarta. ${ }^{10}$ They were among the 416 people that the PUTABA had successfully recruited in 1952, far fewer than the target of twelve hundred workers. Of these 416,229 were Dutch, 111 were German, thirty-nine were Austrian, and eighteen were Italian. In total, 186 were doctors and pharmacists. ${ }^{11}$ For the year 1952, the government decided to budget to import eight thousand foreign workers, based on a tally coordinated with the various ministries. The quality of many of the

The East Asian Society (Ost-Asiatische Gesselschaft) and the Institute for Tropical Medicine (Institut fur Tropen Medizin) in Hamburg received the visitors with some enthusiasm and a German-Indonesian Association was created, but little seems to have come of it.

J. Krol, 'Internationale technische hulp aan Indonesia', Cultureel Nieuws uit Indonesia, 2 (August 1951), 12.

10 Antara, 21 August 1952.

11 Antara, 31 August 1953. 
applicants was disappointing. Some of the Swiss youths sent to Indonesia had received only very basic training. ${ }^{12}$ According to Syafruddin Prawiranegara, the problem then seemed to be less one of getting them into the country than one of getting them out of it. ${ }^{13}$ In general, Indonesian efforts to obtain foreign expertise to work directly and organically within the national civil service were a failure. The PUTABA continued its work until the mid 1950s, but the number recruited lagged far behind what was needed. ${ }^{14}$

\section{Post-colonial Dutch Higher Education}

Prior to the cessation of the colonial relationship, the Netherlands provided a significant amount of schooling for Indonesians. In fact, in the year after the signing of the RTC, the Netherlands was practically the sole provider of foreign higher education to Indonesian youths. ${ }^{15}$ The list below shows the number of Indonesian students who went to the Netherlands to study during the 1950s. While this number was relatively limited during the revolutionary period, it had climbed by the end of the 1940s, peaking briefly between $195^{\circ}$ and 1953, before falling towards the end, in 1957. The number sent during this period was comparable to the total number of Indonesians studying in the Netherlands in the period 1924-1940 (344). Not included in this number were 36o Indonesian Chinese students. ${ }^{16}$

Basuki Gunawan's study of Indonesian students in the Netherlands showed that the similarity in the educational curriculum and methods, the use of the Dutch language, and the prestige of going to the Netherlands to study were factors valued by early Indonesian students, but that feelings of inferiority and a fear of not being able to find a permanent government position at home were negative considerations. ${ }^{17}$ The Malino scholarship, announced after the

\footnotetext{
12 These Swiss youths were receiving Rp 1,500 per month, with a 10,000 Swiss franc bonus per year.

13 NA, Hoge Commissariaat Indonesië, inv. no. 442.

14 PUTABA paid for Dutch professors to teach in Indonesia, including K. Posthumus and J. A. L. Cuisiner at Universitas Gadjah Mada; P. L. van den Velden, F. Weinreb, and P. N. Drost at Universitas Indonesia; and C. G. G. van Herk at Universitas Indonesia in Bogor in $195^{2}$. Putusan2 Rapat ke-31 Kabinet Ali Sastroamidjojo Tanggal 19 Djanuari 1954, ANRI, Kabinet Presiden Republik Indonesia, inv. no. $9 \mathrm{~h}$.

15 Basuki Gunawan, Indonesische studenten in Nederland (The Hague: W. Van Hoeve, 1966), 31 .

16 Murray, A Chronicle of Indonesian Higher Education, 29.

17 Gunawan, Indonesische studenten in Nederland, 31.
} 
TABLE 3 The number of Indonesian students coming to the Netherlands per year

\begin{tabular}{lc}
\hline Year of arrival & $\begin{array}{l}\text { Number/ } \\
\text { percentage }\end{array}$ \\
\hline 1946 & $11(3 \%)$ \\
1947 & $11(3 \%)$ \\
1948 & $32(9 \%)$ \\
1949 & $36(10 \%)$ \\
1950 & $42(12 \%)$ \\
1951 & $59(17 \%)$ \\
1952 & $56(16 \%)$ \\
1953 & $50(14 \%)$ \\
1954 & $25(7 \%)$ \\
1956 & $27(8 \%)$ \\
1957 & $2(1 \%)$ \\
Total & $351(100 \%)$ \\
\hline
\end{tabular}

SOURCE: GUNAWAN, INDONESISCHE STUDENTEN IN NEDERLAND, 33

Malino conference in 1946, allowed for a continued Indonesian presence in the Dutch education system, ${ }^{18}$ at least until the complete cessation of the relationship with the Netherlands in 1957. Unease about the steadily worsening Dutch-Indonesian relationship impacted the desirability of Dutch higher education. Of the two hundred Indonesian students interviewed between 1955 and 1957, 70 per cent admitted their desire to study elsewhere. ${ }^{19}$

The government sent 284 Indonesians with civil service obligations (ikatan dinas) and 142 with foreign aid scholarships to study in the Netherlands during the period 1950-1956. In total, 426 Indonesians studied in the Netherlands in this period. In comparison, the number of students who went to the United States to study between 1950 and 1962 totalled just fifty-nine. In fact, the country that the government sent the next largest number of students to was West

18 NA, Ministerie van Buitenlandse Zaken, Hoge Commissariaat Bandung, 1950-1957, inv. nos. 514-523.

19 Gunawan, Indonesische studenten in Nederland, 31. Especially in the United States, the U K, Scandinavia, Switzerland, and Egypt. 
Germany, where 242 studied. ${ }^{20}$ In the academic year 1952-1953, 1,540 students from Indonesia went to study in Dutch colleges and universities, compared to just eight Indonesian students who studied in Paris. Of these 1,540, 188 were on civil service scholarships and 187 on military scholarships. Higher education for Indonesian students in the Netherlands experienced a significant shift in the post-colonial period. Between 1924 and 1940, the majority of Indonesian students studied at Leiden, especially at its law school, while only a limited number went to the engineering school in Delft. In fact, out of the total of 344 Indonesians who pursued Dutch higher education at this time, 199 studied in Leiden and just twenty-five in Delft. ${ }^{21}$

There were two reasons for the shift in educational emphasis. First, the majority of Indonesians who could afford to go to Dutch universities during the colonial period hailed from the traditional aristocracy, whose main role was within the colonial bureaucracy. Since the colonial bureaucracy focused on the application of Dutch laws, there was an emphasis on legal studies for aspiring bureaucrats. This contrasted with the motivations of students in the postcolonial period. Second, many of those who went to the Netherlands in the 1950s were paid for by the government or received a Malino scholarship, and thus they were expected to supply the manpower needs of the state. Economic deterioration and inflation meant that many, including former members of the aristocracy, had diminished incomes that did not allow them to send their children abroad to study. The state and its access to state and foreign scholarship thus determined who was able to obtain a foreign education.

Glassburner remarked that Indonesia has probably accomplished more by way of eliminating her high-level manpower gap than she has in any other area of economic development policy'.22 In 1949/1950, there were only six higherlearning institutions in Indonesia, ${ }^{23}$ with the number of students totalling 3,377 . By 1955, there was a total of twenty-seven higher-learning institutions, with

20 Rifai, Perkembangan Perguruan Tinggi di Indonesia, 224-6.

21 Murray, A Chronicle of Indonesian Higher Education, 29.

22 Glassburner, 'High-Level Manpower for Economic Development', 201.

23 Universitas Indonesia, Universitas Gadjah Mada, NIAS (Nederlands Indische Artsen School), STOVIT (School tot Opleiding van Indische Tandartsen, which became Universitas Airlangga in 1954), Universitas Nasional, and the Police Academy (Akademi Kepolisian) in Jakarta. 
TABLE 4 Indonesian students studying in the Netherlands in the early 1950s

The universities Number of Indonesian students

Technische Hogeschool Delft 68

Universiteit van Amsterdam 44

Rijksuniversiteit Leiden 42

Economische Hogeschool 16

Rotterdam

Middelbare Technische School

Rotterdam

Hogere Textielschool Enschede 14

Others

Total

18,122 students enrolled. By 1964/65, there were 355 institutions of higher learning, with a total student body of 278 , ooo. In comparison, in the academic year 1939/1940 there had been just 1,693 students enrolled. Between 1950 and 1959, eight universities were founded. Based on Law No. 22/1961, every province was to be furnished with one higher-education institute, preferably a university, and the ratio between the science and engineering faculties and the social/behavioural sciences and humanities was to be seven to three. ${ }^{24}$ As a result, from 1960 to 1966 , twenty-eight universities were founded throughout the archipelago. ${ }^{25}$

There were several ways in which universities were created: some started out as individual faculties that were incorporated into fully fledged universities, while others were created from scratch, either by individuals or groups in civil society or the government. A number of universities started as private institutions that were later incorporated into state universities. These institutions were usually created by prominent regional and national civilians and military elites, who were concerned about providing their areas with higher education while they were at the same time intent on elevating their status

\footnotetext{
24 Rifai, Perkembangan Perguruan Tinggi, 8.

25 Gerhard Junge, The Universities of Indonesia. History and Structure (Bremen: Bremen Economic Research Society, 1973), 28.
} 
by becoming the founder of a higher-education institute. ${ }^{26} \mathrm{~A}$ large number of private universities were not incorporated into state universities. For instance, the University of Res Publica (present-day Trisakti) was created by the Chinese organization Baperki and was also highly influenced by the communists. ${ }^{27}$ By 1959, there were around eighty private universities/schools and, as part of the enthusiasm for the early Guided Democracy developmental push, this had grown to 114 by $1961 .^{28}$

Aside from universities, ministries and private institutions also created academies. By 1954, fifteen academies had been created with courses at them ranging from two to five years' duration. The Ministries of Education and Culture (Kementerian Pendidikan dan Budaja), Foreign Affairs (Kementerian Luar Negeri), Commerce and Industry (Kementerian Perdagangan dan Industri), Public Works (Kementerian Pekerdjaan Umum), and Defence (Kementerian Pertahanan) each had an academy, while the Ministry of Agriculture (Kementerian Pertanian) had three and the Ministry of Transportation (Kementerian Perhubungan) had four. The total number of people taught in ministerial academies in 1955 totalled 1,128, with the largest number studying the three-year course at the Academy of Military Law.

The total number of government employees studying in 1958 was 25,672 . About 43 per cent, or 11,042, were students with civil service obligations. Of those 11,042 students, 1,427 were enrolled in a course of more than three years' duration, 4,068 were on a three-year course, 3,383 were on a two-year course, 2,115 were on a one-year course, and just forty-nine were on a short course of six months' duration. The largest group came from the Ministry of Agriculture $(8,111)$, followed by the Ministry of Health $(7,055)$, the Ministry of Education and Culture $(2,351)$, and the Ministry of Transportation $(1,634) \cdot{ }^{29}$ This expansion of civil service obligations was in line with the massive expansion of government academies, but also with the expansion of government-owned universities. The number of academies would reach a total of 128 by 1970, with the largest growth occurring between the years of 1961 and 1970, when seventytwo academies opened. ${ }^{30}$

The government realized early on that the idea of educating civil servants on a four-year university course would not meet contemporary needs. The urgent demand for trained workers for the business world could not be covered

\footnotetext{
26 Murray, A Chronicle of Indonesian Higher Education, 145-54.

27 Murray, A Chronicle of Indonesian Higher Education, 150-1.

28 Murray, A Chronicle of Indonesian Higher Education, 87.

29 Kursus-kursus Departemen dan Djawatan, vii-viii.

30 Murray, A Chronicle of Indonesian Higher Education, 131.
} 
TABLE 5 List of academies run by Indonesian ministries

\begin{tabular}{|c|c|c|c|}
\hline & Name of school & Overseen by & $\begin{array}{l}\text { No. of } \\
\text { students }\end{array}$ \\
\hline 1 & Academy of Indonesian Art & $\begin{array}{l}\text { Ministry of Education and } \\
\text { Culture }\end{array}$ & 173 \\
\hline 2 & $\begin{array}{l}\text { Academy for the Foreign } \\
\text { Service }\end{array}$ & Ministry of Foreign Affairs & 80 \\
\hline 3 & $\begin{array}{l}\text { Academy for Foreign } \\
\text { Economic Relations }\end{array}$ & $\begin{array}{l}\text { Ministry of Commerce/ } \\
\text { Industry }\end{array}$ & 72 \\
\hline 4 & Academy of Forestry & Ministry of Agriculture & 28 \\
\hline 5 & $\begin{array}{l}\text { Academy of Agricultural } \\
\text { Research }\end{array}$ & Ministry of Agriculture & 76 \\
\hline 6 & Governmental Sucrose College & Ministry of Agriculture & 65 \\
\hline 7 & $\begin{array}{l}\text { Academy of Technical } \\
\text { Education-Foundation }\end{array}$ & Ministry of Public Works & 142 \\
\hline 8 & Higher Education for the PTT & & \\
\hline 9 & $\begin{array}{l}\text { School for Technical Experts } \\
\text { for the Railways }\end{array}$ & $\begin{array}{l}\text { Ministry of } \\
\text { Communications }\end{array}$ & 183 \\
\hline 10 & Academy of Navigation & $\begin{array}{l}\text { Ministry of } \\
\text { Communications }\end{array}$ & 44 \\
\hline 11 & $\begin{array}{l}\text { Academy of Commercial } \\
\text { Navigation }\end{array}$ & & \\
\hline 12 & Academy of Military Law & $\begin{array}{l}\text { Ministry of } \\
\text { Communications }\end{array}$ & 16 \\
\hline 13 & $\begin{array}{l}\text { National Academy of } \\
\text { Engineering }\end{array}$ & $\begin{array}{l}\text { Ministry of } \\
\text { Communications }\end{array}$ & 26 \\
\hline 14 & $\begin{array}{l}\text { Indonesian Academy of } \\
\text { Commerce }\end{array}$ & Ministry of Defence & 223 \\
\hline 15 & Academy of Economics & $\begin{array}{l}\text { Subsidized (less than 100\%) } \\
\text { Private } \\
\text { Private }\end{array}$ & $\begin{array}{l}307 \\
\mathrm{n} / \mathrm{a} \\
\mathrm{n} / \mathrm{a}\end{array}$ \\
\hline
\end{tabular}

SOURCE: DEVELOPMENT OF EDUCATION IN INDONESIA (JAKARTA: MINISTRY OF EDUCATION, INSTRUCTION AND CULTURE, 1955), 13 
either. Efforts to hire Dutch specialists from the Dutch-controlled Indonesian business world had been unsuccessful. Many of the people entering business, regardless of whether their background was administrative or technical, were former government civil servants of Dutch origin. Importing them from the Netherlands was expensive and many of the prospective workers were not attracted unless they were given some guarantee of safety and financial security.

The development of new curricula and modes of study was an essential component of the Indonesianization effort and was dependent on the presence of American faculty teachers, which was a requirement of the university-touniversity cooperation agreements. By the mid 1960s, the new Indonesian curriculum was based on the American model. ${ }^{31}$ We will take a closer look at the cooperation between Kentucky University and the Institute of Agriculture Bogor (Institut Pertanian Bogor, IPB) to see how this shift from the Dutch to the American educational system occurred. It was not purely a re-creation of Indonesian universities as exact clones of American ones:

With Indonesian acuity, the staff at IPB was maintaining some of the system they had learned from the Dutch, studying systems elsewhere in Europe and Asia, refining their own expectations, and utilizing the innovative judgments of Ken-team colleagues. Out of all this it was finding identity as the Indonesian Agricultural University. ${ }^{32}$

It was thus a selective process of de-Europeanization, Indonesianization, and Americanization.

On 30 January 1950, the government issued an emergency law on university education that replaced Staatsblad 1947 no. 47. The formation of an InterUniversity Committee (Panitya Antar-Universitas) signalled the end of the dualism that had existed between the Republican and Federal systems of higher education. The Dutch domination of administrative functions had ended; the

31 Since the early 1950s, calls for a shift from the use of Dutch to English had been made by various educational organizations. ANRI, Kabinet Presiden Republik Indonesia, inv. no. 109 o.

32 Howard W. Beers, An American Experience in Indonesia. The University of Kentucky Affiliation with the Agricultural University of Bogor (Lexington: University Press of Kentucky, 1971), 109 . 
TABLE 6 American university cooperation programs

$\begin{array}{ll}\text { University and faculty } \quad \text { Affiliation } & \begin{array}{l}\text { Financial } \\ \text { support }\end{array}\end{array}$

Universitas Gadjah Mada

\begin{tabular}{|c|c|c|}
\hline $\begin{array}{l}\text { Economics } \\
\text { Mathematics/physics/ } \\
\text { technology }\end{array}$ & $\begin{array}{l}\text { University of Wisconsin } \\
\text { UC Los Angeles }\end{array}$ & $\begin{array}{l}\text { Ford Foundation } \\
\text { ICA }\end{array}$ \\
\hline \multicolumn{3}{|l|}{ Universitas Indonesia } \\
\hline Medicine & UCsF Medical Center & ICA \\
\hline Economics & UC Berkeley & Ford Foundation \\
\hline Agriculture and Forestry & University of Kentucky & ICA \\
\hline Animal Husbandry & University of Kentucky & ICA \\
\hline \multicolumn{3}{|l|}{ Universitas Airlangga } \\
\hline Medicine & UCsF Medical Center & ICA \\
\hline Teaching college Institut & sunY, Albany (State & Ford Foundation \\
\hline Teknologi Bandung & University of New York) & \\
\hline $\begin{array}{l}\text { Engineering/mathematics/ } \\
\text { chemistry/biology/physics }\end{array}$ & University of Kentucky & ICA \\
\hline Universitas Sumatera Utara & & \\
\hline Teaching college & sunY, Albany & Ford Foundation \\
\hline Universitas Padjadjaran & & \\
\hline Teaching college & sunY, Albany & Ford Foundation \\
\hline
\end{tabular}

SOURCE: BRUCE GLASSBURNER, 'HIGH-LEVEL MANPOWER FOR ECONOMIC DEVELOPMENT: THE INDONESIAN EXPERIENCE', IN F. H. HARBISON AND C. A. MYERS, MANPOWER AND EDUCATION. COUNTRY STUDIES IN ECONOMIC DEVELOPMENT (NEW YORK: MCGRAWHILL, 1965), 186. AFFILIATION AGREEMENTS IN 1960

new president of the new and unified Universitas Indonesia was an Indonesian, Soerachman Tjokroadisoerjo, who resigned in $195^{1}$ and was replaced by Professor Soepomo. The process of reshuffling professors continued throughout the 1950s, as faculties that were politically sensitive moved into Indonesian hands, while Dutch professors were permitted to teach courses in specific technical fields that were non-political. ${ }^{33}$ Thus 8 o per cent of the professorial staff

33 The university presidents also held a meeting in April $195^{2}$ and decided that the Dutch language should be replaced as soon as possible with Indonesian. ANRI, Kabinet Presiden Republik Indonesia, 1950-1959, inv. no. 109o. 
in the faculties of law in all state-owned universities was Indonesian, while engineering faculties had no Indonesian teachers. ${ }^{34}$ As explained by the chair of the Council of Curators (Dewan Kurator): 'It is a consequence of our freedom that we must push through this nationalization. This applies especially for courses that are concerned with national administrative leadership. ${ }^{35}$

The government responded to the lack of lecturers in several ways. First, experts working in government services were required to temporarily allocate time for teaching. A second effort was made to import lecturers from abroad. A dozen Dutch professors were invited to teach at various universities for a period of six to twelve months. Throughout the 1950s, Indonesia imported a number of lecturers for the universities. In July 1957, there were 148 permanent foreign lecturers, consisting of eighty-five professors, sixty-three assistant lecturers, and 120 non-permanent lecturers. Indonesia imported thirty-one lecturers in 1955, thirty-seven in 1956, and just eight in 1957. Many of these were brought to Indonesia under the aid schemes of UnEsco, the Colombo Plan, and the Ford Foundation. ${ }^{36}$ By the end of the 195os, the increase in the number of Indonesian faculty members had resulted in the gradual but significant Indonesianization of the university system. For instance, at the Universitas Indonesia in 1951-1952, of 471 members, only 19o, or 40 per cent, of the faculty were native Indonesians, with the remaining 241 , or 6 o per cent, consisting of non-native Indonesians, including around two hundred Dutch professors. By 1953, seventy-five Dutch professors remained; by 1956, there were perhaps only some thirty-five Dutch lecturers. ${ }^{37}$ By $1962-1963$, 99 per cent of the 1,273 faculty members were Indonesian. As most professors in the early 1950s were still Dutch, this Indonesianization resulted in a lower level of education among the teaching staff. ${ }^{38}$

In his acceptance speech as the new president of the UI in 1951, Professor Soepomo indicated that the post-colonial university was functioning in a period rife with internationalism. Aside from receiving professors, Indonesian universities also regularly sent professors on short-term stints abroad. The UN and its panoply of new international organizations provided some relief in the

34 Locomotief, 25 November 195 o.

35 Notities no. 18 over 'concordant' onderwijs (A) cultuur en Indonesisch onderwijs (B), NA, Hoge Commissariaat Bandung, inv. nos. 514-523.

36 'Rapat Kerdja Menteri PP\&K dengan Seksi E DPR', Suara Guru, 7/2 (September 1957), 4-5; ANRI, Kabinet Perdana Menteri Republik Indonesia, inv. no. 529.

37 Bruce Lannes Smith, Indonesian-American Cooperation in Higher Education (East Lansing: Institute of Research on Overseas Program, Michigan State University, 196o), 28.

Murray, A Chronicle of Indonesian Higher Education, 49. 
provision of professors. In 1951, Gadjah Mada acquired two professors from the world Health Organization (wHO) and one from Unesco, and in May of that year, Professors Sardjito and Johannes attended unesco conferences. ${ }^{39}$

The need to educate civil servants, especially in the executive and administrative branches, was acknowledged by the Ministry of the Interior (Kementerian Dalam Negeri) early on, especially in connection with decentralization and regional autonomy. The ministry focused on providing academic and semi-academic education, providing more teaching opportunities at local universities. Prospective civil servants were screened at local and national levels and then admitted to the social science, law, and political faculties of the Universitas Gadjah Mada (UGM)..$^{40}$ In $195^{2}$, the UGM was the only university in the country that provided the kind of education required for executive and administrative civil servants.

Aside from civil servants, the Ministry of Education and Culture also provided scholarships for up to 150 non-civil servants with an ikatan dinas. This required them to work for the government after they had finished their studies. ${ }^{41}$ The need to expand the education of civil servants paralleled the expansion of Gadjah Mada itself. In 1954, the university created a sister faculty at Surabaya's new Airlangga University, focusing on law, economics, and social and political science. Airlangga was developed from an extension of its Medical Faculty and had once been part of the Universitas Indonesia. A Surabaya branch of the Gadjah Mada Law Faculty was inaugurated on 9 April 1955, whereby lecturers from Gadjah Mada would be appointed as extraordinary lecturers at Airlangga. Airlangga's first president was Abdoel Gaffar Pringgodigdo, who also hailed from Gadjah Mada. ${ }^{42}$

\section{The Rise of the Guided Study}

The shift towards a new curriculum was part of what was called the 'total reorganization' that affected old and new universities alike. Unsurprisingly, the old core universities - Universitas Indonesia, Universitas Gadjah Mada, and some of their earlier offshoots including Padjadjaran, Hasanuddin, and Universitas Sumatra Utara - had difficulty coping with the transition. Many of these

39 M. Sardjito, 'Laporan Tahunan Universitit Negeri Gadjah Mada', 19 Desember 1951, 6-10.

40 Education for the staff of the Ministry of Justice was also to be provided through the UGM, according to Justice Minister Wongsonegoro, Harian Indonesia, 13 March 1951.

$41 \quad$ Antara, 14 August 1952.

42 Murray, A Chronicle of Indonesian Higher Education, 96-100. 
universities still hosted Dutch professors and Dutch-educated teaching staff. Although most Dutch professors had left by 1957, the teaching staff required a bit of cajoling before they were truly comfortable with the new curriculum. An Indonesian member of the teaching staff at the IPB commented that everyone used the system that they were familiar with:

This is natural because it is difficult to switch to another system with which one is not familiar. It was not so much that they were 'pushing', but that they were used to their own system and naturally considered it better. In the early stages of the affiliation this was felt more than now because IPB participants after returning began to use more of the American system which they had learned, so prevalence [of the guided system] gradually grew. ${ }^{43}$

The main reason for this change was not merely the need for Indonesia to break out of its colonial mould and take the reins in education. It was, in fact, a matter of efficiency, or the extreme lack of it, within the national education system. ${ }^{44}$ To begin with, although the expansion of Indonesians studying in the national university system was very rapid, there was a lag in the number of graduates. On average only 20 per cent of the student body passed the yearly exams. Although the duration of a sardjana muda (equivalent to a bachelor's degree) was four years, it took many students eight or even ten years to complete their degrees.

The 'inefficient' Dutch system, which was called the 'Free Study' system, was contrasted with the 'efficient', American-inspired 'Guided Study' system, a terminology that paid homage to the Guided Democracy experiment. Under the Dutch Free Study system, a secondary-school leaver was not required to pass an entrance exam to get into university. Students had no obligation to attend lectures. Exams were oral and if the student failed, the exam could be retaken. In fact, 60 to 70 per cent of students failed their exams the first time. Little guidance or structure existed within this system. In addition, the lack of facilities, books, and laboratories in Indonesia's fledgling university system resulted in many drop-outs and demotivated students. ${ }^{45}$ The Guided Study method

43 Beers, An American Experience in Indonesia, 156.

44 This was not simply related to the curriculum. Problems persisted with the issue of funding and the bureaucratic relationship with the central government. Kesukaran-kesukaran pada Universitas Indonesia, ANRI, Kabinet Presiden Republik Indonesia, 1950-1959, inv. no. 1217 .

45 See, among others, Smith, Indonesian-American Cooperation in Higher Education; Murray, A Chronicle of Indonesian Higher Education; Kenneth Lee Neff, 'Educational Planning in 
introduced the entrance exam. The student was required to attend mandatory courses and take written exams. The semester was introduced. Rote memorization and lectures were replaced with discussion groups. Students were expected to complete their degrees within the required time frame.

\section{The International Aid Protocol}

President Truman's administration was pivotal in constructing the global governance structure that was predicated on efforts to reduce the possibility of another conflagration and thus was a systematic plan for peace. ${ }^{46}$ As well as the Keynesian Bretton Woods institutions of the International Monetary Fund (IMF) and the World Bank, the Marshall Plan and the Point Four Program, a technical assistance programme for 'developing countries', were created to reduce the possibility of communist expansion. ${ }^{47}$ The focus on Asia was mainly directed towards China and Japan. The Economic Cooperation Administration (ECA) did provide technical assistance for smaller Asian countries (not including Indonesia), but these represented small, technical aid projects. The Point Four Program, announced in 1949, created a bureaucratic infrastructure for international technical assistance and focused on foreign direct investment, working under the assumption that economic expansion could forge peace and democracy. 48

The provision of technical assistance was a multilateral exercise involving a variety of nations, with the United States taking the reins and initially providing some 6o per cent of the total aid of the United Nations Technical Assistance Administration. ${ }^{49}$ Commonwealth countries that were members of the Colombo Plan also provided help, mirroring American initiatives. The aim was to reduce the appeal of communism and redefine the asymmetrical relationship away from the colonial one in which, as people within the

a National Development Context: Indonesia, a Case Study', PhD dissertation, American University, Washington DC, 1965; Beers, An American Experience in Indonesia.

46 Robert A. Pollard, Economic Security and the Origins of the Cold War, 1945-1950 (Colombia University Press: New York, 1985), 10-32.

47 Pollard, Economic Security and the Origins of the Cold War, 133-67.

48 Pollard, Economic Security and the Origins of the Cold War, 205-9.

49 David Webster, 'Development Advisors in a Time of Cold War and Decolonization: The United Nations Technical Assistance Administration', Journal of Global History, 6/2 (July 2011), 249-72. Aside from the UNTAA, there were also other forms of assistance organization, such as the WHO, the Food and Agricultural Organization (FAO), UNESCO, the International Labour Organization (ILO), and the International Civil Aviation Organization (ICAO). 
dependency school would put it, the creation and management of the Third World was manifested. ${ }^{50}$ At the other end of the spectrum, Soviet assistance after the death of Stalin in 1953 shifted towards a less military approach and the adoption of a subtler attitude towards the underdeveloped parts of the world.$^{51}$ Communism would also be promoted through the power of aid. ${ }^{52}$ This crusading zeal for modernity and modernization, often expressed through the images of industrialization, mega-infrastructure, and the technological capability of humans to revamp whole landscapes, was a modern fetish that was revered everywhere in the post-war society.

This confluence of ideology in the specific modernity brought about by technical assistance experts and the development-minded politicians and leaders of newly independent nations was significant. Soviet aid to Indonesia dwarfed that of the United States, yet no pro-Soviet economists ever came close to the influence that American or Western economists had on Indonesia's planning community or intellectuals. Three-quarters of all Soviet aid delivered between 1954 and 1968 was in the form of military assistance, and those experts that had been sent to help with industrialization were, for the most part, engineers. In fact, as Indonesian economists would find out in their study of Eastern European societies during the Guided Democracy, most Soviet managers were engineers. ${ }^{53}$

These elite engineers may not have been the preachers of modernity that the social scientists of the West were. Yet, many Western technical experts weren't capitalist themselves in the traditional sense. They had to sell the idea of state-sponsored development in the capitalist West. David Webster grouped many of them as Fabian Socialists, a political term which, according to Anne Booth, equated well with Indonesian social democrats. ${ }^{54}$ Many of them saw planning as the holy grail of development. As Webster phrases it, 'Colombo Plan members approached planning with an attitude approaching "worship". 55

$5^{\circ}$ Arturo Escobar, 'Power and Visibility: Development and the Invention and Management of the Third World', Cultural Anthropology, 3/4 (November 1988), 428-43.

$5^{1}$ Jeffrey F. Taffet, Foreign Aid as Foreign Policy. The Alliance for Progress in Latin America (Hoboken: CRC Press, 2007), 14.

52 Orah Cooper and Carol Fogarty, 'Soviet Economy and Military Aid to the Less Developed Countries, 1954-1978', Soviet and Eastern European Foreign Trade, 21/1-3 (Spring-Fall 1985), 54-73.

53 Panglaykim and Hazil, Struktur Management dan Organisasi dalam Beberapa Negara Sosialis (Jakarta: Pembangunan, 1962), 16-18.

54 Anne Booth, 'The Colonial Legacy and its Impact on Post-Independence Planning in India and Indonesia', Itineratio, 10/1 (1986), 13 .

David Webster, 'Development Advisors in a Time of Cold War and Decolonization', 258. 
As we will see, the 1950s' Indonesian technical elite also shared the same political ideology, with many of them having been influenced by Dutch social democracy, the political system that they were exposed to during their sojourn in the Netherlands; by socialist ideas; and, perhaps, even by Japanese fascist/ corporatist notions. The social scientist and technical expert Benjamin Higgins, for instance, believed that state-owned companies could effectively stimulate economic growth. ${ }^{56}$ This was a sentiment shared by many Indonesian experts, especially considering the utter lack of an indigenous entrepreneurial class and the seeming impossibility of imagining a free, market-based economy within the Indonesian society of the 195 os. $^{57}$

On 4 December 1949, a UN resolution was passed on the composition of technical assistance. It covered aspects such as the deployment of a team of experts to assist countries as advisers, the training of experts from less-developed countries abroad, the training of experts and auxiliary personnel within the country, the deployment of personnel and materials for specific projects, and the exchange of information. In May 1950, a mission from the UN Secretariat visited Indonesia, along with agents from UNESCO, the FAO, and the wHO. UNESCO, the WHO, and UNICEF would help Indonesia to develop an education system for the people, and with rural reconstruction and various health initiatives. ${ }^{58}$

\section{Development of Indonesian-American Aid Relations}

During the revolutionary war, a group of Indonesian officials, comprising mostly PSI intellectuals, went to establish a lobbying organization in the United States. Sumitro Djojohadikusumo and Soedjatmoko were hosted by an American group concerned about the growing clout of communism in Asia, and met with the established circle, especially members of the Council on Foreign Relations, one of the most influential think tanks in the United States. ${ }^{59}$ It was Sumitro's duty to drum up American support for the Indonesian side during the revolution as part of the charm offensive intended to reassure America that a post-colonial Indonesia would not hastily nationalize Western companies and

56 Benjamin Higgins, 'Thoughts and Action: Indonesian Economic Studies and Policies in the 195os', Bulletin of Indonesian Economic Studies, 26/1 (1990), 37-47.

57 Benjamin Higgins, 'Introduction', in Benjamin Higgins (ed.), Entrepreneurship and Labor Skills in Indonesian Economic Development: A Symposium, 22-8.

$5^{8}$ Krol, 'Internationale hulp aan Indonesia', 2-15.

59 Ransom, 'The Berkeley Mafia', 2. 
assets. ${ }^{60}$ The fear that Indonesia would become communist made America cautious about supporting the Republican cause. ${ }^{61}$

In a speech about the Point Four Program and Southeast Asia, Soedjatmoko reiterated the cautiousness of the Asian approach to aid: 'Why is it that no leaders in Southeast Asia immediately hailed this plan, as Marshall's proposals had been immediately seized upon and embraced by the leaders of Europe?' The answer to this was that it was a result of the disillusionment of the elite with America's dithering stance towards Asian independence movements. In particular, it was 'America's failure to make a sufficiently early stand on the issues of colonialism' that had 'left very serious doubts in the minds of many Asians as to America's true intentions'. ${ }^{62}$ Although there was no doubt about the support that the providers of technical assistance had had from within the Indonesian intellectual class, suspicion remained among other groups of Indonesian elites. The suspicion was rooted in, as Soedjatmoko said, the failure of America to act quickly to support the Republic against Dutch aggression during the revolution but was also due to the reservations of many of the elites, who were leftists, about submitting to American control. The fall of the Sukiman Cabinet (April 1951-April 1952) as a result of the signing of the Mutual Assistance Agreement with the United States illustrates this ambivalence towards the West. ${ }^{63}$

During the Second Dutch Military Aggression, Sumitro, who had become a permanent financial and trade representative to the United States and a member of the Indonesian delegation negotiating at the UN in New York, met with the acting US minister of foreign affairs, Robert A. Lovett, on 20 December 1948. The Republican elites had realized that the Netherlands were having difficulty funding their operations without the help of the Marshall Plan. Lovett reassured him that while the Marshall Plan funds for the Netherlands would not be stopped, the money intended for Indonesia had been completely halted. Sumitro held news conferences to gauge the opinion of the American public and thus cemented Indonesia's first important postindependence relationship with the US. His position on Indonesia's economic diplomacy with the United States was stated clearly in his report to the

6o This also included the visit by Soedjatmoko to New York in support of the Marshall Plan. See Ransom, 'Ford Country', 93-116.

61 Frances Gouda and Thijs Brocades Zaalberg, American Visions of the Netherlands East Indies/Indonesia. US Foreign Policy and Indonesian Nationalism, 1920-1949 (Amsterdam University Press: Amsterdam, 2002), 209-14.

62 Soedjatmoko, 'Point Four and Southeast Asia', Indonesië, 4 (1950-1951), 3-4.

63 Feith, The Decline of Constitutional Democracy, 198-207. 
Indonesian foreign minister, H. Agus Salim, titled Indonesian Economic Manoeuvres in America.

Initial contacts with America were strictly through US companies and these were mostly failures. In the various efforts to break through the Dutch blockade of the Republic during the revolutionary war, shipping companies such as Isbrandtsen and the Overseas Corporation tried to smuggle goods to Singapore. Dutch authorities confiscated the Isbrandtsen ship, while the Overseas Corporation got away with the money, costing the Republic some $\$ 500$, o00 worth of rubber and quinine. In 1947, Sumitro, who at the time was the Republican trade representative, along with Minister of Prosperity Adnan Kapau Gani, met with Matthew Fox, a well-known American businessman and vice president of Universal Pictures, to create the Indonesian-American Corporation. ${ }^{64}$ The contract, signed in Havana, Cuba, on 3 January 1949, allowed the corporation to be granted a monopoly over the right to sell some Indonesian commodities. This contract was not valid after the transfer of sovereignty. Homan indicated that as much as $\$ 55$ o,ooo might have been loaned to support the Indonesian delegation in New York. ${ }^{65}$

American aid was institutionally realized through the ECA. In the early 195os, the aid was diverted to Asia as a result of the Korean War and the opening up of East Asia, including Southeast Asia, as an important military front against communism. In June 1950, the director of the Far East Division of the ECA, R. Allen Griffin, ${ }^{66}$ toured Asia in order to be able to recommend the scope and amount of aid needed for the countries/colonies of Southeast Asia. According to his recommendations, Indonesia was to receive the second-largest amount of ECA help (after Indo-China), totalling \$14.5 million. Griffin also recommended that sixty-three technical experts be sent to Indonesia. ${ }^{67}$ The amount that was ultimately given to Indonesia in October 1951 was $\$ 13$ million, which was what was left over from ECA money spent on the Republic of China. ${ }^{68}$ Aside from ECA aid, the US also provided $\$ 100$ million of import credit

64 According to Peter Dale Scott, there was a possibility that Matthew Fox was a front-man for the CIA. Scott, 'Exporting Military-Economic Development', 213. This seems quite unlikely, though, as the US Secretary of State was quite critical of Fox's relationship with the Indonesian government.

65 Gerlof D. Homan, 'American Business Interests in the Indonesian Republic', Indonesia, 35 (April 1983), 125-32.

66 Griffin was an army intelligence veteran and later a trustee of the Asia Foundation, a CIAfunded organization. See Scott, 'Exporting Military-Economic Development', 212.

67 Australian Embassy, Washington, 5 June 1950, Memorandum for the Secretary, Department of External Affairs, Canberra, NAA, series no. A1838. 
from the Exim Bank in February 1950, and a $\$ 5$ million military grant linked to the signing of the Japanese Peace Treaty at the San Francisco Conference in $1951,{ }^{69}$ which had resulted in the fall of the Sukiman Cabinet.

As well as technical help, the Americans were also eager to provide institutional links to ensure that the Indonesian military remained anti-communist. On 3 October 1950, a US mission headed by Mr John F. Melby and Major General Graves B. Erskine arrived in Indonesia with the task of persuading the Indonesian government to accept arms free-of-charge from the US in return for participation in an American military aid programme. The mission was received by the president on 5 October and the American gentlemen held talks with Prime Minister Muhammad Natsir, Foreign Minister Mohammad Roem, Vice Premier Sultan Hamengkubuwono IX, and the chief of staff of the armed forces, General Simatupang. Indonesia was promised a \$10o-million package of aid in goods. ${ }^{70}$ The military aid programme required a certain degree of US control of both the organization and the training of the armed forces, elements that the Indonesian government found hard to accept, even though it was felt that the military needed help in acquiring modern military hardware. ${ }^{11}$

Acceptance of the US military mission was politically impossible, considering the degree of suspicion in which the US was held by many of the leftistleaning parliamentarians. At the same time, the Dutch were carrying out a similar military assistance programme through the Nederlandse Militaire Missie, which made the offer rather redundant. The failure of the Melby Mission did not, however, affect non-military American aid. Griffin had discussed the Colombo Plan mission with the Australians and stressed that each aid programme should be carried out on an individual basis with each country, without the need to create a complex organization. On 6 August 1951, Dr Samuel Perkins Hays was appointed chief of the ECA Special Technical and Economic Mission to Indonesia, replacing Shannon McCune. ${ }^{72}$

Lester Pearson, Canada's first ambassador to Indonesia, called the country 'the first child of the United Nations'. There was a belief amongst many in the West that left to its own devices, Indonesia would fail to develop and modernize. ${ }^{73}$ In fact, quoting the Colombo Plan's technical aid chief, Geoffrey

69 Usha Mahajani, Soviet and American Aid to Indonesia, 1949-1968 (Athens: Center for International Studies, 1970), 6 .

$70 \quad$ Krol, 'Internationale hulp aan Indonesia', 7.

71 Australian Embassy, Jakarta, 12 October 1950, NAA, series no. A1838.

72 DMR, 'US Economist Named Head of Indonesian Mission', 25 June 1950, NAA, series no. A1838.

Webster, Fire and the Full Moon, 79-80. 
Wilson: '[The] United Nations plays a much more important role here (in Jakarta) than in any other country in the area he had visited. Indonesia is desperately short of good Ministers and officials, but many of the United Nations people are good and they have had a long time there to acquaint themselves with local conditions. The result is that they pretty much decide what should be done in the fields in which they operate. ${ }^{74}$ The strength of influence of these foreign experts probably contributed considerably to the contempt and displeasure that people such as Roeslan Abdulgani and Sukarno felt for experts.

Initially, the foreign aid relationship was regulated by the Ministry of Trade and Industry (Kementerian Perdagangan dan Industri) through its Coordinating Bureau for Foreign Assistance (Biro Ko-ordinasi Bantuan Luar Negeri, BKBLN), which was created on 29 December 1950 under the command of C. v.d. Straaten, Achmad Ali, and J. Kramer. After the formation of the National Planning Council (Depernas), an Inter-Departmental Coordinating Committee (Panitia Koordinasi Interdepartemental, Pakin) was formed as a liaison agency for all the government bodies connected with foreign aid. Within the State Planning Bureau (BPN), a section was created to handle foreign assistance, headed by the future economists Ir. Mohammad Sadli and Ir. Sie Kwat Soen. During the Guided Democracy, with the creation of the Depernas and the termination of the BPN in 1959, foreign assistance was transferred to the Financial and Economic Bureau of the Office of the First Minister, usually called the Finek (Finansial dan Ekonomi). ${ }^{75}$

Within the Finek, throughout both the parliamentary and Guided Democracy periods, foreign-assistance relationships, at least civilian ones, were handled by social democrats or PSI-linked individuals at both the BPN and the Finek, which were both pro-Western and anti-communist. These bureaux were positioned under the Office of the Prime Minister (and, later on, the First Minister). Outside the top level of Indonesia's policymaking elite, enthusiasm for foreign assistance was low amongst Indonesian officials. The government was reluctant to allow foreign experts to work at middle or village levels. Two types of foreign personnel were sought: trainers, who would be given little

74 Webster, Fire and the Full Moon, 83.

75 It came under the auspices of the Finek (Biro Ekonomi dan Keuangan) in what was named the Office of Overseas Development (Bagian Kerdjasama Luar Negeri), which was similar to the Coordinating Bureau under the National Planning Bureau. All overseas cooperation had first to be approved by the Ministry of Foreign Affairs. 'Laporan Bagian Kerdjasama Luar Negeri. Biro Ekonomi dan Keuangan, Sekretariat Negara', ANRI, Menteri Negara Ekonomi, Keuangan dan Industri, inv. no. $235^{8}$. 
authority, and experts, who would fill mid-range technical positions within the civil service. ${ }^{76}$

There were two forms of international relations. The first was through a direct contract signed by an expert with an aid agency and its respective national counterpart. For instance, much of the early aid to the National Planning Bureau occurred through this type of relationship, including the sending of economic experts such as Benjamin Higgins and companies such as the J. G. White Engineers Corporation to work on creating Indonesia's national plan. These relationships bypassed the universities, and the experts were contracted to work in a specific government unit, usually policymaking bodies. The second form of relationship was the university affiliation network. These relationships bypassed the structure of foreign recruitment developed by the Ministry of Public Service Employees (Kementerian Urusan Kepegawaian) and the PUTABA office and were regulated by the National Planning Bureau, which had a desk that controlled all international aid relationships. The two institutional matrices are presented in the diagram below. The third diagram shows the regular route for the establishment of a new international aid relationship.

The period 1950-1965 was thus one of massive interaction and transfers between Third World and First and Second World countries. In Indonesia's case, the most significant were the relationships with the American AID organization, the various UN organizations, and the Ford Foundation. The investments from these organizations established institutions within the landscape of the Indonesian state and provided Indonesians with the opportunity to study at various universities in the West in order to 'correct' their mindset and prepare them to run the institutions on their return to their home country.

The data sets above were obtained from the Finek. ${ }^{77}$ They show the number of experts sent to the country by various international agencies throughout the period. America was the country most visited by Indonesians looking to obtain a higher education or technical training. American Aid, meanwhile, consistently provided the most aid money from Western nations throughout the period.

Soviet offers of aid had started relatively early on, in 1948. But as long as Indonesia was under the rule of social democrats, as exemplified by prime ministers Hatta, Natsir, and Wilopo, hostility towards the Soviet Union was strong.

76 'Foreign Technical Assistance in Economic Development in a Newly Independent Country. Some Observations in Indonesia, Economic and Cultural Change, 1/1 (March 1952), 78-9.

77 The Finek took on the management of foreign relations after the disbandment of the BPN in light of the creation of the Depernas. 


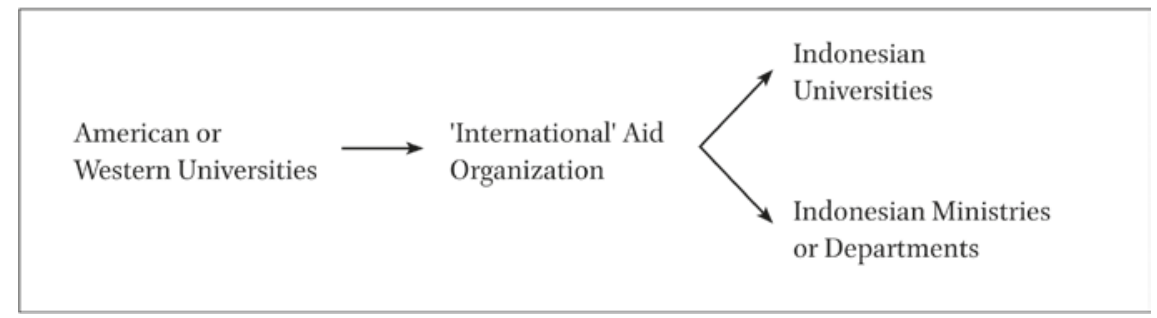

FIGURE 1 University affiliation network SOURCE: AUTHOR.

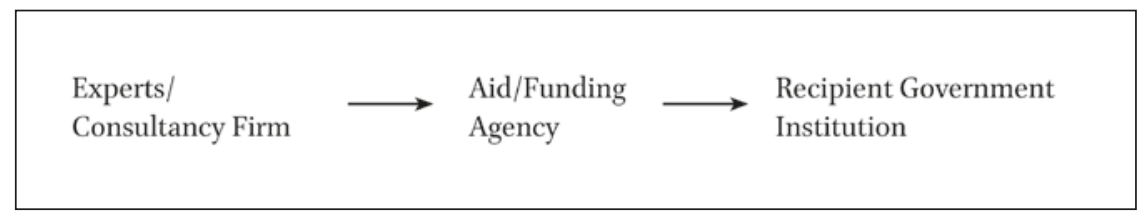

FIGURE 2 Experts funded by aid agency network SOURCE: AUTHOR.

Indonesian Government/ Delegation

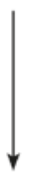

Creation of institution within existing universities or in newly created body<smiles>[3H][Te]</smiles>

Send students to study at Indonesian program
International Aid Organization (USAID, UN)
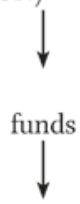

reports/recommendations

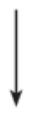

Gets funding for 'Indonesia program' and send experts to help the creation of organization

FIGURE 3 The international aid network in relation to US universities and aid agencies SOURCE: AUTHOR. 


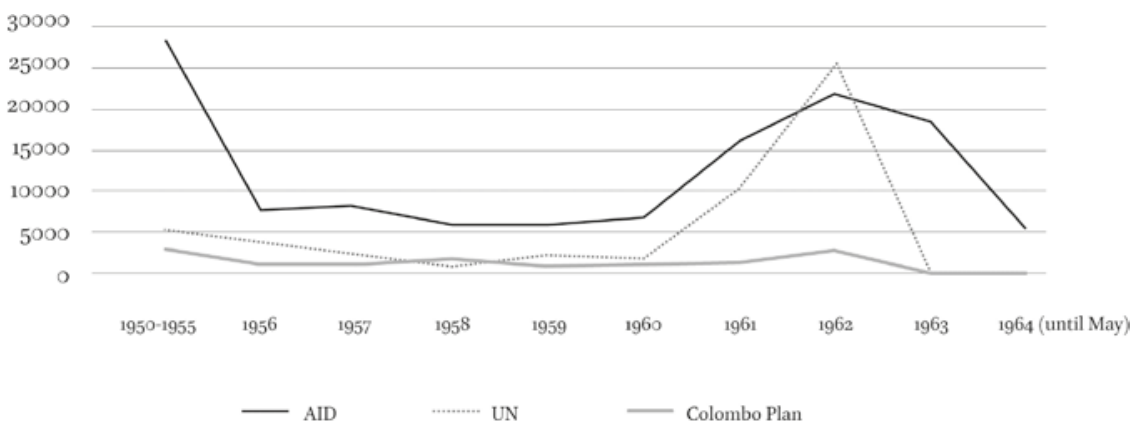

FIGURE 4 Aid per year from American AID, the UN, and the Colombo Plan. Figures represent thousands of dollars. ANRI, Menteri Negara Ekonomi, Keuangan dan Industri, inv. no. 2358. UN and Colombo numbers for 1963 and 1964 were not available

TABLE 7 UN assistance to Indonesia, 1950-1962, ANRI, Menteri Negara Ekonomi, Keuangan dan Industri, inv. no. $235^{8}$

\begin{tabular}{lcc}
\hline Year & Experts & Trainees \\
\hline $1950 / 51$ & - & 19 \\
$195^{2}$ & 64 & 44 \\
1953 & 77 & 22 \\
1954 & 69 & 23 \\
1955 & 78 & 65 \\
1956 & 95 & 54 \\
1957 & 102 & 49 \\
1958 & 100 & 47 \\
1959 & 98 & 44 \\
1960 & 83 & 36 \\
1961 & 93 & 73 \\
1962 & 102 & 118 \\
Total & 961 & 600 \\
\hline
\end{tabular}

When the Wilopo Cabinet fell, in July 1953, there was a shift in Indonesian attitudes towards the Eastern Bloc, due to the dependence of Ali Sastroamidjojo's government on the support of the PKI. This coincided with the death of Stalin and the shift of power to Kruschev and his overtures towards the Third World. Trade and payment agreements were signed with China, Czechoslovakia, East 
TABLE 8 USAID/ECA/ICA assistance, ANRI, Menteri Negara Ekonomi, Keuangan dan Industri, inv. no. $235^{8}$

\begin{tabular}{lrc}
\hline Year & Experts & Trainees \\
\hline & & \\
$1950-1955$ & 112 & 604 \\
$195^{6}$ & 154 & 339 \\
1957 & 160 & 428 \\
$195^{\circ}$ & 178 & 365 \\
1959 & 171 & 349 \\
1960 & 325 & 318 \\
1961 & 510 & 517 \\
1962 & 230 & 394 \\
1963 & 181 & $\mathrm{n} / \mathrm{a}$ \\
$1964($ April) & $\mathrm{n} / \mathrm{a}$ \\
Total (1950-1962) & 2.049 & 3,314 \\
\hline
\end{tabular}

TABLE 9 Colombo Plan assistance, ANRI, Menteri Negara Ekonomi, Keuangan dan Industri, inv. no. $235^{8}$

\begin{tabular}{lrr}
\hline Year & Experts & Trainees \\
\hline & & \\
$1950-1955$ & 23 & 333 \\
1956 & 37 & 414 \\
1957 & 42 & 150 \\
1958 & 47 & 104 \\
1959 & 49 & 139 \\
1960 & 60 & 121 \\
1961 & 15 & 247 \\
1962 & 29 & 216 \\
1963 & 22 & 346 \\
1964 (May) & 9 & 91 \\
Total & 302 & 1,724 \\
& & \\
\hline
\end{tabular}


TABLE 10 Eastern European assistance in the form of scholarships for Indonesian trainees, ANRI, Menteri Negara Ekonomi, Keuangan dan Industri, inv. no. $235^{8}$

\begin{tabular}{lrrrc}
\hline Countries & $\mathbf{1 9 6 1}$ & $\mathbf{1 9 6 2}$ & $\mathbf{1 9 6 3}$ & $\mathbf{1 9 6 4}$ \\
\hline USSR & 50 & 135 & 150 & - \\
Yugoslavia & - & 10 & 20 & 6 \\
Poland & - & 7 & 8 & - \\
Czechoslovakia & - & 30 & 30 & 2 \\
East Germany & 45 & - & 3 & 7 \\
Romania & 11 & 2 & 10 & - \\
Hungary & - & 5 & 11 & - \\
Bulgaria & - & 2 & 5 & - \\
Total & 106 & 191 & 237 & 12 \\
\end{tabular}

Germany, Poland, and the Soviet Union. In 1956, a large Soviet mission concluded a treaty with Indonesia, whereby a $\$ 100$ million long-term, low-interest loan was provided. This was used for road building and various other projects. It was envisaged that technical aid for the Five-Year Plan (Rantjangan Lima Tahun) would be provided by the Soviet Union. ${ }^{78}$

The number of people sent to the Eastern Bloc, especially during the 196os, was quite significant, with over three hundred people sent to study in the Soviet Union at higher-education institutions. Kruschev's visit to Jakarta in 1960 concluded an aid deal in excess of $\$ 700$ million, with a $\$ 250$ million military grant followed by a $\$ 400$ million military grant in 1961 to assist with the struggle for West Papua. ${ }^{79}$ By 1961, Indonesia had become one of the largest noncommunist recipients of Soviet military aid..$^{80}$ Over a billion dollars in military aid would be given to Indonesia throughout the Guided Democracy period, meaning that aid to Indonesia amounted to a third of all aid given to noncommunist countries by the Soviet Union. According to Guy Pauker, the rational reason for Soviet willingness to spend so much on the Indonesian military was to bribe the military to support a communist takeover of the country. ${ }^{81}$

78 Mahajani, Soviet and American Aid to Indonesia, 7-15.

79 Mahajani, Soviet and American Aid to Indonesia, 15-16.

8o A fifth of all Soviet aid to non-socialist countries went to Indonesia. Ragna Boden, 'Cold War Economics: Soviet Aid to Indonesia', Journal of Cold War Studies, 10/3 (Summer 2008), 116. Guy Pauker, 'General Nasution's Mission to Moscow', Asian Survey, 1/1 (1961), 13-22. 
Most of those sent to the Soviet Union went to study engineering and gain the technical know-how needed to run the various Soviet industrial-aid programmes, including the 1962 Asian Games, the Cilegon Steel Plant, the Superphosphate project in Sumatra, the farming mechanization project, and the projected oceanographic institute in Ambon. Over one hundred Indonesian trainees were sent to study petroleum engineering as part of Indonesia's wish to reduce its dependence on Western oil companies, and 125 were sent to study at the Patrice Lumumba University in Moscow. ${ }^{82}$ Conversely, five hundred Soviet experts were sent to Indonesia to supervise the execution of Sukarno's grandiose projects. ${ }^{83}$

\section{$9 \quad$ National Planning and Technical Assistance}

Two important men figured throughout the 1950s in connection with the creation of the Indonesian development plan: the Rotterdam economics graduate Sumitro Djojohadikusumo and the engineer Djuanda Kartawidjaja. Sumitro Djojohadikusumo, the son of well-to-do aristocrat Margono Djojohadikusumo, was born on 29 May 1917 in Kebumen, Central Java. ${ }^{84}$ After completing his secondary education at a European school in Java, he went on to study economics at Rotterdam. He completed his doctorate in 1943 under the Indologist Professor Gonggrijp with a dissertation on small-scale credit. ${ }^{85}$

Because connections between Indonesia and the Netherlands had all but ceased during the war, Sumitro remained in Rotterdam until the end of the war, working at the Rotterdam Hogeschool. After the war, Sumitro initially joined the Dutch delegation as an adviser. ${ }^{86}$ In 1945 , Sumitro returned to Indonesia to edit Berita Perekonomian. He then became an assistant to the Ministry of Finance (Kementerian Keuangan) and to Prime Minister Sjahrir's office. ${ }^{87}$ He became one of the Indonesian representatives in the Office of Permanent Observers of Indonesia at the UN Security Council, alongside Soedarpo

\footnotetext{
82 ANRI, Menteri Negara Ekonomi, Keuangan dan Industri, inv. no. 2358.

83 For more on foreign aid numbers, see Donald Hindley, 'Foreign Aid to Indonesia and its Political Implications', Pacific Affairs, 36/2 (Summer 1963), 107-19.

84 For more on his biography, consult Aristides Katoppo et al., Sumitro Djojohadikusumo. Jejak Perlawanan Begawan Pejuang (Jakarta: Pustaka Sinar Harapan, 2000).

85 Katoppo et al., Sumitro Djojohadikusumo, 1-15.

86 Sumitro Djojohadikusumo, 'Recollections of My Career', Bulletin of Indonesian Economic Studies, 3/22 (1986), 42-4.

87 Webster, Fire and the Full Moon, 78.
} 
Sastrosatomo, Soedjatmoko, and Nicodemus Lambertus Palar. Benjamin Higgins described him as 'one of the most brilliant economists in all Asia.' 88

By 31 March 1950, the Indonesian ambassador to the United States and future premier, Ali Sastroamidjojo, gave a talk at a dinner held in his honour in New York on the Indonesian plea for technical assistance which, according to him, was 'fundamentally a social rather than an industrial reform which must begin with education and technological assistance from all countries of the world which have the advantage of experience. ${ }^{89}$ Later, in June 1951, Sumitro Djojohadikusumo, then adviser to the minister of economic affairs, undertook his European-American tour to look for experts for the State Planning Bureau and the various banks in Jakarta. He had with him a list of 180 expert roles that were needed to formulate and carry out Indonesia's first national plan. Although initially Sumitro wanted to obtain Dutch expertise for at least six important positions in the BPN, he failed to find anyone willing to leave for Indonesia. ${ }^{90}$

In the end, he found help from UnEsco in New York, which promised twelve financial economic experts, who would be paid for by the organization. The BPN was to be headed by an Indonesian, with the foreign experts serving as executive staff members and senior officers. The bureau's position was not that of a 'super department', thus its coordinating capabilities with respective ministers depended much on the tact and capability of its leadership to gain trust and respect amongst the other ministerial members. ${ }^{91}$ The UN's Technical Assistance Board approved Indonesia's request in a meeting on the 24-28 July $1951 .{ }^{92}$ The Indonesian project was greeted with much approval from many within the UNTAA. Indonesia was 'one of the most significant among those we have been privileged to assist in developing'. ${ }^{93}$

\section{State Planning Bureau-UNTAA Cooperation}

The BPN was one of the most important expert bodies in the 1950s. It was created in $195^{2}$ and placed under the Office of the Prime Minister. The BPN also

88 Higgins and Higgins, Crisis of the Millstone, 81; NAA, United States of America - Relations with other countries - Pacific - Indonesia, A1838.

89 'Indonesia Wants Technical Assistance, Envoy Says', 31 March 1950, NAA, A1838.

90 'Internationale technische hulpverlening', 18 Juni 1951, NA, Hoge Commissariaat Indonesië.

91 Sumitro Djojohadikusumo, Bunga Rampai Ekonomi (Jakarta: Indira, n.y.), 259-61.

92 Bureau voor Internationale Technische Hulp, Buitenlandse Deskundigen voor Indonesië, 25 September 1951, NA, Hoge Commissariaat te Bandoeng, 1950-1957.

93

Webster, 'Development Advisors in a Time of Cold War and Decolonization', 26o. 
contained the largest number of experts working on the Indonesian economy. Its control over foreign aid meant that the BPN also controlled the nation's creation of experts. The BPN was not only essential in creating experts but was also important in forging an esprit de corps amongst policymakers and economists. According to the engineer Koesoediarso Hadinoto,

The BPN effectively and productively creates cadres. The experts of the BPN are given the tools to act rationally and capably and also to always act in a nationalist manner to contribute to the state and the nation. These experts are then sent to a variety of government offices and stateowned companies. The emotional bonds that have been created amongst them are kept alive and contribute to aiding cooperation between the offices they lead, in accordance with the approach and problem-solving methods they've learned during their stay at the BPN. ${ }^{94}$

Prior to the arrival of UNTAA experts, the government contracted the engineering consultancy firm J. G. White Engineering Corporation in January 1951, which was financed by the ECA. ${ }^{95}$ By mid January 1951, the corporation's team of consultants had arrived in Jakarta under the leadership of Mr Henry Tarring. The J. G. White consultants worked behind the scenes, drawing little press attention. This suited the Indonesian government, which was wary of being seen to be too dependent on foreign consultants. ${ }^{96}$ Their presence, however, was

94 Ali Budiardjo, 'Abdi Negara dan Abdi Bangsa', in Awaloeddin Djamin (ed.), Ir. H. Djuanda: Negarawan, Administrator, Teknokrat Utama (Jakarta: Kompas, 2001), 255. According to Koesoediarso Hadinoto, 'Biro Perancang Negara benar-benar efektif dan produktif sebagai wadah dan sarana kaderisasi. Para tenaga ahli Biro Perancang Negara dibekali metode berfikir dan bertindak yang rasional dan andal, serta selalu berjiwa kebangsaan dengan itikad berbakti kepada negara dan bangsa. Kemudian para tenaga ahli itu disebarkan ke berbagai instansi Pemerintah serta Badan Usaha Milik Negara. Ikatan batin antara mereka terpelihara secara berlanjut, sehingga memperlancar kerjasama antara instansiinstansi yang mereka pimpin, berdasarkan metode pendekatan dan penyelesaian masalah yang dulu mereka pelajari bersama di Biro Perancang Negara.'

95 Australian Embassy, Jakarta, Memorandum no. 63, 14 February 1951, NAA, A1838, Republik Indonesia Serikat - Foreign Aid to Indonesia. The J. G. White Engineering Corporation were, however, quite successful in developing parts of the Taiwanese industry, including the development of its plastic industry. Nan Wiegersma and Joseph E. Medley, us Economic Development Policies toward the Pacific Rim. Successes and Failures of Us Aid (Basingstoke: MacMillan Press, 200o), 55 .

96 The uproar over the presence of former Nazi finance minister Hjalmar Schacht, whom Sumitro Djojohadikusumo invited to conduct a three-month study of the financial position of the country, offered a good lesson in focusing on low-key deployment. Hjalmar Schacht, Laporan Hjalmar Schacht (Jakarta: Kementerian Penerangan, 1951). 
met with irritation and suspicion amongst the Dutch consultants still working for the government, especially as they feared that long-established Dutch methods would be called into question and that the consultants' involvement would function as a backdoor for American enterprises to gain access to Indonesia. ${ }^{97}$ In terms of creating a national plan, however, the government did not consider the J. G. White Engineering consultants to be very useful. Their suggested plan for industrialization was considered less than stellar.

In June 1952, Professor Benjamin Higgins, who had previously been working in Libya for the United Nations Temporary Executive Authority (UNTEA), was appointed as a UN adviser on monetary and fiscal matters to both the Indonesian Ministry of Finance and Economic Affairs (Kementerian Keuangan dan Urusan Perekonomian) and the State Planning Bureau. In 1954, he returned to Indonesia as director of the MIT Center for International Studies project on Indonesia. In 1959, he left the MIT project to teach at the University of Texas and decided to study Latin America because of his frustration with Southeast Asia's lack of development at the time. ${ }^{98}$ Higgins was one of the world's leading authorities on development economics. He had begun his career teaching economics at the University of Melbourne in 1948 and had worked for the ILO during the war. The importance placed on Higgins's advice by Sumitro was illustrated by the location of his office, which was next door to Sumitro's. ${ }^{99}$

Although the ECA funded much of the research in Indonesia during this period, the coterie of experts had an international character. The first UN technical mission to the BPN consisted of nine experts, four of whom were Canadians, including Benjamin Higgins and Nathan Keyfitz. ${ }^{100}$ In fact, Higgins, as head of the UNTAA mission in Indonesia, hand-picked the entire team, which included American Edgar McVoy, a labour expert who would introduce Indonesia to the Training Within Industry (TWI) labour management programme;101 South African income expert Daniel Neumark; British industrial economist Peter

97 Australian Embassy, Jakarta, Memorandum no. 63, 14 February 1951, NAA, A1838, Republik Indonesia Serikat - Foreign Aid to Indonesia.

98 Higgins, 'Thoughts and Action', 37-47.

99 J. A. C. Mackie, 'In Memoriam: Professor Benjamin Higgins, 1912-20o1', Bulletin of Indonesian Economic Studies, 37/2 (2001), 183-8. He also regularly saw Sjafruddin Prawiranegara, head of the Bank of Indonesia, and attended the bank's weekly board meetings. Higgins, 'Thoughts and Action', 37-47.

100 Webster, Fire and the Full Moon, 78-9. T. R. Smith from New Zealand was to consult on management issues. ANRI, Kementerian Keuangan 1950-1969, inv. no. 276.

101 He had previously introduced the TwI programme to Japan and Malaya. Alan G. Robinson and Jean M. Schroeder, 'Training, Continuous Improvement and Human Relations: The us Twi Program and the Japanese Management Style', California Management Review, 35/ 2 (Winter 1993), 35-56. 
Diebold; migration expert D. M. Deane; and New Zealand education specialist T. R. Smith. ${ }^{102}$ Many of the UN technical assistance experts were civil servants who believed in Keynesian economics and Fabian social-democratic ideals. British Fabian values were cherished in the PSI circle. ${ }^{103}$ This meant that there was a considerable ideological affinity between Sumitro and Higgins. ${ }^{104}$

Higgins wielded his huge authority without much democratic oversight. Although Djuanda was the head of the BPN, ${ }^{105}$ it was Higgins who went abroad to seek international aid and it was he who reviewed these aid programmes. It was his decision to renew the J. G. White Engineering Corporation contract, for instance. ${ }^{106} \mathrm{He}$ wrote that the Indonesian government accepted his advice with 'frightening willingness'. In a Colombo Plan meeting, one observer wrote that people had mistaken him, instead of Djuanda, as head of the BPN. ${ }^{107}$ Such enormous freedom for the technical assistance team saw Higgins praising the country:

In Sjafruddin and Sumitro, the country had a duumvirate on economic policy that few underdeveloped countries could match for competence and commitment to the national interest. The Wilopo Cabinet was composed of extraordinarily able and honest men. In the Planning Bureau and its relationship to other government agencies abroad, the country had an effective instrument for development planning. ${ }^{108}$

In 1957, when Djuanda was appointed prime minister, leadership of the BPN went to his right-hand man, Ali Budiardjo. Budiardjo had been secretary general to the minister of defence under Sultan Hamengkubuwono IX, ${ }^{109}$ another

\footnotetext{
102 ANRI, Kementerian Keuangan, inv. nos. 293, 294.

103 Feith, The Decline of Constitutional Democracy, 130.

104 Webster, Fire and the Full Moon, 80-1. 'PSI policies were "remarkably similar" to those being developed by the national CCF in the same period.' The CCF was the Co-Operative Commonwealth Federation of the government in Saskatchewan, Canada, which relied on social-democratic planning.

105 ANRI, Kabinet Presiden Republik Indonesia 1950-1959, inv. no. 1381.

106 Memorandum from Benjamin Higgins to Minister of Finance Sumitro Djojohadikusumo on the renewal of the J. G. White contract, ANRI, Departemen Keuangan 1950-1969, inv. no. 294. According to a BPN file, the J. G. White Engineering Corporation was still working for the BPN in January 1955. ANRI, Kabinet Presiden Republik Indonesia, 1950-1959, inv. no. 1381 and Departemen Keuangan 1950-1959, inv. no. 294.

107 Webster, Fire and the Full Moon, 84.

108 Higgins and Higgins, Crisis of the Millstone, 88.

109 I. O. Nanulaita, 'Ir. Haji Djuanda Kartawidjaja', in Awaloeddin Djamin, Pahlawan Nasional Ir. H. Djuanda Kartawidjaja. Negarawan, Administrator dan Teknokratutama (Jakarta: Kompas, 2001), 110.
} 
technocratic figure, from 1950 to 1953. In May 1953, Sumitro had offered him the job as interim director general of the BPN before Djuanda took the reins. Like many intellectuals, he was close to Sjahrir during the Japanese occupation. He earned a master's degree at MIT's School of Industrial Management in $1962 .{ }^{110}$ Djuanda and Budiardjo worked closely with one another until the dissolution of the BPN in 1959 and the transfer of Budiardjo into Djuanda's Financial and Economic (Finek) Bureau under the Office of the Prime Minister. He played a seminal role in helping to create the Depernas. Thus, during the transition to Guided Democracy, there was some continuity for the planning bureau due to the existence of this relatively small bureaucratic body placed deep within the government.

With a highly fragmented government and little ability to coordinate amongst themselves, new institutions were created to take over the jobs that the ministries were supposed to accomplish, all of which were placed under the control of the Office of the Prime Minister. The universities were part of that institutional framework. The Institute for Economic and Social Research (Lembaga Penjelidikan Ekonomi dan Masjarakat, LPEM) at the Jakarta School of Economics (Fakultas Ekonomi), University of Indonesia fulfilled the role of the ministries. The institute, along with the National Planning Bureau and the Department of Industry, studied the development of industry after independence, publishing its findings in January 1954. Because it was a university-based institution, it was able to compile, interpret, and appraise the data in an independent and objective way. ${ }^{111}$

Perhaps no other higher-learning institution held such an important place in modern Indonesian history as that of the FEUI. This was due to the role Sumitro Djojohadikusumo, institution builder par excellence, played in its development. He built the faculty from the ground up and persuaded Dutch professors who were in Indonesia to teach, even though many of them were not trained economists and taught 'old-fashioned' economics. Sumitro reformed and overhauled the economics curriculum of the country: the legal-continental approach taught by Dutch professors was replaced with a more Keynesian approach. Sumitro wanted to create a Jakarta School of Economics that would be

\footnotetext{
110 With a thesis titled 'Management Education in Indonesia'.

111 Sumitro Djojohadikusumo, The Government's Program on Industries. A Progress Report by the Institute for Economic and Social Research (Jakarta: LPEM, 1954), 1-2.
} 
at the leading edge of economics research. He wanted to introduce developmental economics in which the state, not the firm, would be the main focus of analysis. According to Emil Salim, it was he who introduced macroeconomics to Indonesia, away from the focus on the firm, in which many of the Dutch professors had specialized. ${ }^{112}$

Sumitro's relationship with the Americans provided access to scholarships and research money from the West. In 1951, he signed an agreement with Everett Hawkins, who was working at the ECA at the time. The ECA gave a $\$ 400$,ooo grant to finance American economists to teach at the faculty. Although he was in contact with the Ford Foundation when it opened its office in Jakarta in $195^{2}$, he was only able to coax an agreement from them by 1956 . His agreement with the Ford Foundation and the University of California, Berkeley enabled some of the brightest economics students in Indonesia to continue their studies in the US. Twenty students were sent to various universities in the United States in several batches. ${ }^{113}$ This, of course, enabled the rise of the notorious 'Berkeley Mafia', which was headed by Sumitro's most able student and the lead technocrat of the New Order, Widjojo Nitisastro. ${ }^{114}$

Sumitro also played a central role in the creation of the LPEM, which was funded by the Ford Foundation and became a centre for research and a place where young social scientists were able to obtain practical experience through internships at the B PN. In 1955, Sumitro founded the Association of Indonesian Economists (Ikatan Sardjana Ekonomi Indonesia, ISEI), a professional organization. ${ }^{115}$ Through the formation of such institutions and through the links they had with American funding organizations, a class of experts, or in Higgins' words, a 'community of scholars', was created that had both an esprit de corps and a similar ideological approach to the main questions plaguing the nation.

The shift in education also represented a shift in the thinking of the nation. The Ford Foundation thus made English-language education a central component of its aid. ${ }^{116}$ What had to change was not merely the language, but how that language conveyed a different set of assumptions about the perception of reality. The 195os thus not only saw a shift from Dutch to English, but also a shift in the sound bites that peppered elite speech. A look at the newspapers of

112 Goenawan Moehammad, Celebrating Indonesia. Fifty Years with the Ford Foundation. 19532003 (Jakarta: Ford Foundation, 2003), 48-6o.

113 Moehammad, Celebrating Indonesia, 48-6o.

114 Other members included Ali Wardhana, Soebroto, Daoed Joesoef, J. B. Soemarlin, Emil Salim, J. E. Ismael, and Dorodjatun Kuntjoro-Jakti.

115 Moehammad, Celebrating Indonesia, 46-7.

116 Bresnan, At Home Abroad, 34. 
the decade shows an increasing use of English words such as efficiency, national planning, and management. Thus, the expansion of American education, books, and other materials created a significant cultural change. These changes were wrought through magazines and other cultural media, which heralded what Vickers called 'the atomic age.'117

The first Ford Foundation delegation visited Indonesia on 7 July 1952. They stayed from 12 August to 11 September 1952 and visited Jakarta, Bandung, Yogyakarta, and Surabaya. The report of the visit outlined the importance of Indonesia to the foundation: 'Because of the speed with which Indonesia has advanced from colonial to sovereign status, because of the complex and difficult problems it faces with few resources in trained personnel, and because its ability to transform itself into a modern state without becoming a totalitarian regime or falling into anarchy is important to all of the free world, Indonesia is today a country of unique significance.'118 The report concluded that Indonesia needed trained personnel, as there were more 'economists in Washington working on the Indonesian problem than there are in all Indonesia'. Sukarno had impressed Brown and Arnold immensely and they were able to confirm the approval of a \$150,00o grant to send American English teachers to Indonesia in 1953-1954. They offered help to train vocational teachers and to establish an institute for public administration. ${ }^{119}$

They also stressed the need for greater knowledge of the country. In 1951, the Ford Foundation provided a grant to Stanford University to investigate the state of Asian studies in the US, and in $195^{2}$ it granted eighty-three fellowships in the study of Asia and the Middle East. In 1953, the Foundation gave a $\$ 125,000$ research grant to MIT to study economic development in Indonesia, India, and Italy. This was part of a larger research initiative at the MIT Center for International Study, which included research into communist societies by Walt Rostow and a study of the formation of public opinion in France led by Daniel Lerner. ${ }^{120}$ The Indonesia Program was the result of a three-week discussion

117 Adrian Vickers, $A$ History of Modern Indonesia (Cambridge: Cambridge University Press, 2005), 126-33.

118 Quoted in Bresnan, At Home Abroad, 27.

119 Bresnan, At Home Abroad, 31-3.

120 Benjamin Higgins, 'The Indonesia Project of the Massachusetts Institute of TechnologyCenter for International Studies', Ekonomi dan Keuangan Indonesia, 3 (1955), 151-4. 
between the director of the centre, the director of the project, and various Indonesian officials, both in the government and at Universitas Indonesia. The focus of the research was on financing economic development, patterns of trade, the technological aspects of economic development, management and administrative techniques, and quantitative studies. ${ }^{121}$

The programme also researched a wider variety of topics related to economic growth in Indonesia. These studies were meant to offer a precision instrument to understand the underlying problems of the economy, thus 'providing the analytical knowledge which must precede the use of the surgeon's corrective knife.'122 The programme's focus on government administration and the labour supply led to more extensive political change becoming one of the recommendations of the study. Studies in collaboration with Universitas Gadjah Mada painted a picture of a passive Indonesian society, waiting for government intervention: 'The government is regarded as the accepted agent for introducing new techniques of production and exchange, and the population is quite willing to accept changes in economic institutions so long as they do not greatly alter the existing social and cultural patterns. ${ }^{\prime 23}$

The project supported the shift to a welfare-state system of government, under which the state would provide infrastructural development such as transportation infrastructure, education, and social welfare programmes in order to create a labour force ready for the coming industrialization. A study of the tax base, government efficiency in utilizing this tax base, the economic impact of taxation, patterns of government expenditure, and the relationship between the government's capacity for developmental investment and government borrowing and structures were all important areas of study for helping to understand the relationship between the government and economic development. A history of trade union movements and their relationship with economic development, the political structure of the country and its relationship with foreign aid, and other forms of social science research all provided a multidisciplinary approach to tackling the problems of economic development. ${ }^{124}$

The funds provided by the International Training and Research Institute enabled Max Millikan, head of the Center for International Studies at MIT, to send, among others, Douglas Paauw to study fiscal structure, Benjamin Higgins to look at national income, and Guy Pauker to study the political environment.

\footnotetext{
121 Higgins, 'The Indonesia Project', 155-7.

122 Douglas Paauw and William C. Hollinger, 'Research Plan for Indonesian Economic Development', Indonesia Project Plans 1, 18 February 1953.

123 Paauw and Hollinger, 'Research Plan for Indonesian Economic Development'.

124 Paauw and Hollinger, 'Research Plan for Indonesian Economic Development'.
} 
Guy Pauker would become influential during the 196os, helping to strengthen the relationship between the new generation of economists and the military officers within the Seskoad. ${ }^{125}$ The MIT project was the result of cooperation amongst social scientists at Harvard and MIT to study various problems of the post-war world, from communication to communism and economic development. ${ }^{126}$ Benjamin Higgins, head of MIT's Indonesian Project, questioned the professional quality of the research being carried out by these academics, ${ }^{127}$ signalling his dissatisfaction with the programme. Unlike the UNTAA programme, their relationships with, and attachment to, the National Planning Bureau were unsuccessful.

Benjamin Higgins was struck by how his work with the MIT project was practically the same as when he had been an official adviser to the government under the UNTAA. At no other time in Indonesian history have so many foreign experts had such a large amount of authority within the Indonesian government. They were not only researching, designing institutions, and developing new systems, but also actively producing Indonesia's next wave of economists and social scientists. Discussions on economic policy were conducted within what was called Sumitro's 'kitchen cabinet': ${ }^{28}$ by the board of directors of the Bank of Indonesia, by the BPN and its working group, at the Harmonie Club, and in the journal Keuangan dan Ekonomi Indonesia.

In 1956, in cooperation with Sumitro, the foundation started shipping in American economists, mostly from the University of California, Berkeley, to take over the roles left by departing Dutch professors. A new post-graduate economics programme had begun and Indonesian faculty members had the opportunity to study abroad at prestigious universities in the US for a $\mathrm{PhD}$ in economics. The first group included Widjojo Nitisastro and Mohammad Sadli. The second group included economist Emil Salim. By 1962, the Ford Foundation, through the University of California had trained some forty economists. Between 1953 and 1965, the Ford Foundation funnelled \$15 million worth of aid to Indonesia, practically all in the form of education. Around four hundred Indonesians had been given fellowships to study abroad - most of them as part of a long-term plan to build a national system of teaching colleges, focusing on English, science, and mathematics. ${ }^{129}$ Many of these American-trained

125 He was one of the supporters of the idea of the army as a positive force for reform and a provider of leadership. Guy Pauker, The Role of the Military in Indonesia (Santa Monica: Rand Corporation, 1960), 59-65.

126 Higgins, 'The Indonesian Project', 152-9.

127 Bresnan, At Home Abroad, 76.

128 A group of unofficial advisers with undue influence.

129 Bresnan, At Home Abroad, 66. 
economists would teach the courses run for higher-echelon military personnel at the Military Academy (Seskoad) in Bandung as part of the Leknas-Seskoad cooperation agreement. It was on these courses that Suharto met with many of the economists who would craft the economic policy of the New Order for him.

\section{The 1956-196o National Plan and Guided Democracy}

The National Plan was finally written in 1956, but only ratified by Parliament in 1959. Later, during the transition to Guided Democracy, Benjamin Higgins's idea of the Big Push was central; it was 'big mainly in the ratio of savings and investments to national income,'130 that is, in calculating the incremental capital-to-output ratio to determine the rate of efficiency of investment both from foreign investment and domestic savings. Although Higgins contributed to writing the plan, he had no final say.

Higgins was quite critical of the plan and thought it weak, especially in relation to statistics and numbers. The population growth assumption of $1.7 \mathrm{per}$ cent was considerably on the low side. The Incremental Capital Output Ratio, put at two to one, was also considered too low. The targets were too modest and indicated compromises with the political elites. Take-off growth was assumed to happen at the level of Rp 12-15 billion investment per year, yet the plan targeted Rp 6 billion in investment in the first five years and it was only in the fourth Five-Year Plan that a figure would be reached that would support take-off growth. No austerity measures on consumption were taken to reallocate capital to the productive sector; in fact, only 40 per cent of the increase on per capita income would be reinvested, the rest would go to consumption. The plan also assumed that private and foreign investment would supply 6o per cent of capital needs, yet the necessary reform measures for investment incentives in areas such as land policy, squatting policy, tax, and monetary policy had not been carried out, although a foreign investment, mineral, and oil bill was passed. ${ }^{131}$

By the time that the plan was ratified by Parliament, the period it covered had almost ended. Significant changes in economic and political aspects of the country had made it redundant. Inflation had spiked as a result of massive deficit spending when the country lurched into civil war, and Sumitro, along with colleagues from the PSI and Masjumi, joined the PRRI rebellion in

\footnotetext{
130 Higgins and Higgins, Crisis of the Millstones, 71.

131 Benjamin Higgins, 'Introduction', in Douglas Paauw, Financing Development. The Indonesian Case (Glencoe: The Free Press, 1959), 15-28.
} 
Sumatra. The National Planning Board (Dewan Perantjang Nasional, Depernas) had replaced the State Planning Bureau, and this new planning agency was focused on a broader range of issues in line with the Guided Democracy's revolutionary intention, producing an eight-year national plan that was written by non-economists and heavily criticized for being unrealistic.

Yet, social scientists like Benjamin Higgins were initially positive about the early Guided Democracy. Prime Minister Djuanda was seen to be a sensible, technocratic choice, which augured well for sober, less grandiose, and more rational planning. Sumitro's earlier industrial plans had failed because of the lack of administrative and entrepreneurial capabilities. Higgins pointed out several changes in the way that the Indonesian leaders viewed the situation. The relationship between political stability and economic growth was much clearer; economic growth was a precursor to redistribution. Higgins believed that communist involvement had been discredited due to its role in nationalization, and he thought that the cultural idea of a village consensus had been discredited too. ${ }^{132}$ This upbeat view of the Guided Democracy was shared by many in the modernist camp of the Kennedy Administration of the United States. ${ }^{133}$ There was a deep underlying belief that rational Indonesian technocracy was just under the surface, struggling to break free and take over the national leadership.

\section{Foreign Experts and Indonesian Authority}

American aid was a rather sensitive subject in Indonesia. Although the country was more predisposed to the Western bloc in the early 1950s, Suraputra noted that 'most Indonesians feel that their country lies much more exposed to the economic and military power of the United States and associated countries than it does to Soviet Russia or China'.134 The root of this elite ambivalence for the US was the perceived notion that the US had backed the Netherlands during the revolutionary period, later had approved Dutch control of West Papua, and, after the outbreak of war in 1958, had given clandestine support to the rebels in Sumatra, West Java, and South Celebes. This view of America affected the way Indonesia interacted with the US throughout the period. ${ }^{135}$

\footnotetext{
132 Higgins, 'Introduction', 46.

133 Bunnell, 'The Kennedy Initiatives', 85-9o.

134 D. S. Suraputra, 'The Role of American and Soviet Aid to Indonesia', MA thesis, Institute of Social Science, The Hague, 1967, 5 .

135 Daniel Novotny, Torn between America and China. Elite Perception and Indonesian Foreign Policy (Singapore: Institute of South East Asian Studies, 2010), 105-7.
} 
Foreign experts were concentrated within the office of the B PN and around Sumitro Djojohadikusumo and Benjamin Higgins. Others, such as Edward Lichtfeld and Alan C. Rankin, or the Kentucky Team at the Agricultural Institute in Bogor, were part of a panoply of specific projects for the development of certain parts of the Indonesian expert production system. The Five-Year Plan, with its focus on a Big Push dependent on foreign investment, was politically unacceptable. Yet, the failure of the BPN's Five-Year Plan showed how weak the authority of this expert group was. Sukarno's Guided Democracy achieved a coup d'état over this weak authority. Parliamentary democracy and the political party system were often considered the primary quarry of Sukarno's Guided Democracy policy, yet his main target was the PSI and their Masjumi political supporters and, by extension, the main intellectual experts in the country.

By 1958, a large proportion of the intellectual experts, including Sumitro, had defected to the PRRI rebellion. Asked by Kennedy whether Indonesia's intellectuals backed Sukarno's government, Soebandrio, who had accompanied the president on his 1961 trip to the US, had answered, "The Indonesian intellectuals are a reactionary group. They cannot be asked to participate in the revolution.' ${ }^{136}$ When Soedjatmoko, a leading intellectual and friend of Soebandrio, asked Soebandrio why, his answer was that Sukarno deeply resented intellectuals. For those within the intellectual circles, the first shock came from the result of the 1955 election, in which the PSI, the intellectual party par excellence, garnered a measly 5 per cent of the vote. Four parties came out of the election as major players in Indonesian politics: the nationalist Sukarnoist PNI, the modernist Muslim Masyumi, the traditional Muslim NU, and the communist PKI. ${ }^{137}$

Despite being politically weak, those surrounding the BPN, primarily Indonesian and American, Canadian, and Australian experts, formed what Benjamin Higgins called a 'community of scholars'. This included economists such as Higgins, Douglas Paauw, and William Hollinger; political scientists such as Guy Pauker, Jean Mintz, and Ruth McVey; and anthropologists such as Clifford Geertz and the members of his field team, which included Alex Dewey, Donald Fagg, Hildred Geertz, Edward Ryan, and Robert Jay. ${ }^{138}$ The 'community of scholars' also transcended geographic boundaries and created connections between places, from the BPN and FEUI to the Boston-Cambridge area, Wisconsin and Ithaca in the US, and Windsor and Montreal in Canada.

\footnotetext{
${ }_{13} 6$ Rosihan Anwar, Sukarno, Tentara, PKI. Segitiga Kekuasaan sebelum Prahara Politik, 19611965 (Jakarta: Obor Indonesia, 2001), 46.

137 Feith, The Decline of Constitutional Democracy, 424-40.

138 Mackie, 'In Memoriam: Professor Benjamin Higgins', 183-8.
} 
These geographical points, the headquarters of universities, perfectly characterized the institutionalized technical aid world, which functioned as a provider of experts and as a legitimizer of its own brand of modernization theory. Within the MIT Center for International Studies, these experts included sociologist Daniel Lerner, whose work on the passing of traditional society had made a significant contribution on Anglo-Saxon modernism. ${ }^{139}$ The economists included Paul Samuelson, Evsey Domar, and Robert Solow, whose work on the Solow-Domar growth equation later earned them Nobel prizes. George Kahin at Cornell; Everett Hawkins, Hans Schmidt, and Ted Morgan in Wisconsin; Bruce Glassburner in California; and scholars from McGill and the University of British Columbia represented an array of very distinguished names in the social sciences who were working to decipher Indonesian modernity. Especially important in this regard was the group's access to President Kennedy when he was making policy decisions. Walt W. Rostow recalled the situation: 'Kennedy sought out and found in CENIS a group whose ardent commitment was to enlarged development aid rather than to party or political personality. He understood this clearly and used us well.'140 Rostow, along with Max Millikan, became what Nils Gilman called Kennedy's 'mandarin of modernity'.141

There was an expansion of intellectual interest in Indonesia. New books on Indonesia gradually replaced Dutch works after the shift from Dutch experts and advisers to American ones around $1957 \cdot{ }^{142}$ Significantly, these social scientists were, as Higgins admitted, clueless about economic development, and tried to figure out the system that was most suited to the Indonesian condition. Albert O'Hirschman, another technical expert and modernization theorist, said: 'I went to Colombia in 1952 without any prior knowledge of [...] development [...] [I later] discovered I had acquired a point of view of my own that was considerably at odds with current doctrines. ${ }^{143}$ Knowledge production was thus a confluence of the anti-communist ideology of American modernization and the harsh realities of localized context.

139 Daniel Lerner, The Passing of Traditional Society: Modernizing the Middle East (Glencoe: The Free Press, 1958).

140 Taffet, Foreign Aid as Foreign Policy, 20.

141 Gilman, Mandarins of the Future, 115-202.

142 The Dutch had a long tradition of planning in Indonesia, especially in social programmes, but this differed from the large and intricate periodical developmental plans that became the economic policy of the New Order. Despite this, some of these Dutch projects continued after independence. See Leonard Blussé et. al., India and Indonesia from the $1920 s$ to the 1950s: Origins of Planning (Leiden: Brill, 1987).

143 Kirk S. Bouman, Military, Democracy and Development. The Perils of Praetorianism in South America (University Park: Pennsylvania State University Press, 2002), ix. 
In terms of the role of government, there was no doubt among anyone who had been to Indonesia that a government-led economic plan was the only way in which Indonesia could move forward. ${ }^{144}$ This role differed considerably from the state planning of the Soviet Union or communist China, but it was also very different from the freewheeling capitalism of yesteryear. Yet, for all the state-led ideas that had been discussed during the period, the situation of the Indonesian state as a parliamentary democracy was never disputed. It was accepted that the political problems and the country's instability were issues that were negatively affecting the capability of the state, resulting in what Gunnar Myrdal called a 'soft state', ${ }^{145}$ but there never seems to have been any discussion of a change in the political landscape of Indonesia. It would obviously have been impudent for foreign experts to suggest something that was definitely outside their area of authority, but even in discussions with Indonesian economists such as Sumitro Djojohadikusumo or Sjafruddin Prawiranegara no one seems to have brought up the idea of changing the political system.

Awareness that the military was becoming a major proponent of both political stability and economic development grew only gradually and not obviously. Political scientists like Guy Pauker would gradually realize the potential of military men and think of them as the most promising and rational of the Indonesian elite, but this realization would not come about until the late 195os. When Sukarno started his campaign to bury the party and initiate a major change in state-society relations, Sumitro, Sjafruddin, Mohammad Natsir, and many of the more technocratic-minded elite of Indonesia rebelled against the central government. It was this discrepancy between the old intellectuals of the 1950s and the new intellectuals who had started to emerge by the late 195 os that was to be one of the more significant factors of the period.

At the international level, the 195os was a rather naïve decade. President Eisenhower's policy on aid contained no specific strategy other than to support economic and social development. It was hoped that such assistance would push economic growth and thus reduce the temptation of communism in much of the developing world. By the end of the 1950s, the world had seen a series of developments which had toppled democracies in many developing nations. Parliamentary democracy was being discredited on an international

144 This does not mean that state-led economic centralization was the only option available. Experts also discussed the possibility of decentralized economic development. For instance, Douglas Paauw, 'The Case for Decentralized Financing of Economic Development in Indonesia', The Far Eastern Quarterly, 15/1 (November 1955), 77-95.

145 Gunnar Myrdal, The Asian Drama. An Inquiry into the Poverty of Nations (Middlesex: Penguin Books, 1968), 891-90o. 
scale and the American response was to change its aid strategy. Instead of development per se, the Kennedy-era approach to aid was to connect it intimately with the war on communism, thus redirecting aid to military purposes. The Kennedy Doctrine and the creation of the Alliance for Progress shifted the provision of aid towards a political goal.

Through education and community development, an increase in the capabilities of the individual went a long way towards easing the transformation of Indonesia from a traditional society to a modern, industrial one. But there were no discussions in the 1950s that talked about the kinds of pervasive and invasive action that would be conducted by the Guided Democracy state, nor did anyone talk about the role of the military in this regard. This idea of control was what was missing within the discourse of 1950s' experts. This was to be the main idea developed during the Guided Democracy by both its proponents and its intellectual opponents, whose shared 'chameleon-like' hypocrisy, to use a phrase coined by the journalist Mochtar Lubis for the second-generation economists, allowed both groups to cultivate a new relationship of power within a new notion of population control and development.

\section{Conclusions}

The Americanization of various aspects of the creation of an Indonesian elite was met with resistance in many forms. The inertia of the bureaucracy pushed for the continuation of 'Dutch' ways of doing business and, in fact, these continued as a result of the sheer limitation of the American impact on the large Indonesian bureaucracy. At the regional and local level there was little American presence; the changes occurred in the central institutions - the major universities and schools created through expert recommendations - and at national planning institutions. As a result, the Americanization was a flimsy affair, with changes occurring within small, almost separate institutions, whose effects on the vertical level were generally unknown but considered to be very limited. Yet, these developments paved the way for the Guided Democracy's institutional experiment. The next two chapters discuss the Guided Democracy state and the implementation of the various ideas that shaped it. These include the corporatist ideas that stemmed from the colonial and Japanese period, and were succinctly expressed in the 1945 Constitution, and the various developments that occurred during this period. This development of the idea of Indonesian society was important, for it cemented in place models of state-society relations that would continue throughout the second half of the twentieth century. 